\title{
Effect of Climate Change Associated Hazards on Agricultural Workers and Approaches for Assessing Heat Stress and Its Mitigation Strategies - Review of Some Research Significances
}

\author{
Govinda Pal*, Thaneswer Patel and Trishita Banik
}

\author{
${ }^{1}$ North Eastern Regional Institute of Science and Technology (NERIST), \\ Nirjuli, Arunachal Pradesh, India \\ ${ }^{2}$ Uttar Banga Krishi Viswavidyalaya (UBKV), Cooch Behar, West Bengal 736165, India \\ *Corresponding author
}

\section{A B S T R A C T}

\section{Keywords}

Climate change

hazards,

Agricultural

workers health,

productivity, Heat

stress assessment, protection, Future research

\section{Article Info}

\section{Accepted:}

22 January 2021

Available Online:

10 February 2021
The effect of climate change is one of the most significant intimidations to mankind after the Covid-19. Due to the nature of agricultural work, i.e., outdoor work environment, climate change has a more severe effect on agricultural workers. Hence the agricultural workers are more exposed and vulnerable to climate change-related hazards and hot environments. Therefore, the study on the impact of climate change associated hazards on the hours' agricultural workers' needs. An extensive literature review has been conducted for systematic segregation and representation of available information towards drawing inferences on climate change associated hazards on agricultural workers, effect of heat stress, and mitigation strategies. We have collected the literature by systematically reviewed available literature from various sources like Scopus, Google Scholar, Embase, CrossRef, Science Direct, and PubMed database and hardcopy of journals. The current review discusses climate change-related hazards like extreme weather events, extreme heat, air pollution, high level of $\mathrm{O} 3$, psychological stress, ultraviolet exposure, vectorborne diseases, and other biological hazards affect tremendously outdoor agricultural workers' health, which leads to low income in the agricultural sector. It also suggests possible future research directions to develop better strategies for preventing the effect of climate change on agricultural workers.

\section{Introduction}

Climate change is one of the foremost concerns globally as its effect on human health and livelihood (Detz, 2020). It also strongly influences the ecology, environment, and economics of a country and raises many risks for outdoor workers in occupational hazards (Adam-Poupart et al., 2013; Roelofs and Wegman, 2014; Levy and Patz, 2015;
Applebaum et al., 2016; Schulte et al., 2016; Leavy et al., 2019). In the present situation, climate change is one of the most significant threats to mankind after the Covid-19 (Hunter and Hewson, 2020). Agriculture is a highly important sector where excessive numbers of workers are needed, as lots of human efforts are required to accomplish the agricultural work (FICCI, 2015; Pal and Chattopadhyay, 2020). In the case of agricultural workers, 
climate change is a more severe issue than any others, as most of the farming work is generally being done in an outdoor work environment (StaalWästerlund, 2018).

Agricultural farmworkers who are mostly work in an outdoor environment often come across the risk of climate change-related hazards and hot situations (Kiefer et al., 2016). Climate, change-related hazards like extreme weather events, extreme heat, air pollution, high level of $\mathrm{O}_{3}$, psychological Stress, ultraviolet exposure, vector-borne diseases, Lyme disease, and other biological hazards, are affecting tremendously outdoor agricultural workers' health and productivity (Moda et al., 2019; Kiefer et al., 2014; Shortridge et al., 2018; Padhy et al., 2015; De et al., 2005; Rim et al., 2014; Poupart et al., 2014; Nicholas H. Ogden, 2017; Lucas et al., 2014; Sett et al., 2013; Schulte et al., 2009; Mathee et al., 2010; Sorensen et al., 2018; Cogato et al., 2019). Besides, the heat waves due to climate change affect the precipitation, which causes a negative impact on the agricultural sector (Kumar et al., 2014). Agricultural workers may be particularly vulnerable to climate change threats because they are bound to work in hot environments that induced heat disorders (ILO, 2019; Kovats et al., 2008). Due to occupational heat exposure in a tropical developing country, farmers easily come across heat stress, heat illness, and occupational injury, which may eventually cause death (Xiang et al., 2014; Kjellstrom et al., 2014; Kovats et al., 2018; Hancock et al., 2002). On the other hand, the heat-related disorder in farmers playsa significant role in the accident, fall, and heart attacks (Steve Sutter, 1994). To fulfill the livelihood and overcome the economic problem, many agricultural workers are unable to escape climate change threats (Olsson et al., 2014). Further, climate change influences the farmer's life indirectly by affecting the economic sectors in extremes precipitation and higher temperature (Kim, 2009; Cogato et al., 2019; Burney et al., 2014). Besides, Sea level rise and flooding due to climate change directly affect coastline fishing communities and farmers (Barange et al., 2018).

From the view of earlier research, we found that climate change influences the ozone layer, which leads to an increase in U.V. radiation intensity in the earth's atmosphere. More prolonged exposure of outdoor farmworkers to more intense and frequent U.V. radiation may increase skin cancer risk, impaired immunity, and eye effect (Moda et al., 2019; Kiefer et al., 2 014; Schulte et al., 2009; Flouris et al., 2018). Besides, the rising temperature due to climate change enhances air pollution, which is related to chronic health consequences, like an allergic reaction, respiratory diseases, low productivity, etc. (Moda et al., 2019; Ahmed et al., 2015; Neidell et al., 2017). Apart from, agriculture is already a hated profession where climate change will enhance labor migration from the agricultural trade (Barnett and Webber, 2009). Moreover, outdoor farmworkers are losing their productivity due to climate change and higher workload intensity (Bugajska et al., 2005; Kjellstrom et al., 2016). To mitigate all the effects of climate change on farmers needs proper protection and adaptation strategies.

Because of the lack of appropriate, relevant data, it has been difficult to assess how vulnerable and at-risk the impacts of climate change on agricultural workers. To address these issues, it may be useful to develop a framework for identifying how climate change could affect agricultural workers' health. This article appraises comprehensive reviews of different studies with the objectives to evaluate the consequences of various researches on the effect of climate change-related hazards on agricultural workers, approaches for assessing the impact 
of heat stress on agricultural workers' health, and highlighted some of the protection approaches of farming workers to mitigate the effect of climate change.

\section{Materials and Methods}

After systematically reviewing the previous published priorities, we filter some selected data and utilize those selected data to achieve our objectives. We take a deep insight from our review to elaborate on the effect of climate change on agricultural workers' health, identify different popular heat stress methods for assessing the impact of heat stress on agricultural workers' health, and recommend adaptation strategies to prevent the effects.

The systematic review of the previous published priorities is executed with the standard Preferred Reporting Items for Systematic Reviews and Meta-Analyses: The PRISMA Statement (Moher et al., 2009). We have reviewed one hundred forty-two publish documents, including full-length papers, books, and websites from 1996 to 2020, to recognize relevant noble reviewed articles. After the revisions of different research priorities with the help of Scopus, Google Scholar, Embase, CrossRef, Science Direct and PubMed database and appropriate international and national agencies websites, a comprehensive perception on the issue was considered in the review that supports to elaborate the impact of climate change on farmworkers, method heat stress assessment and its adaptation measures. Out of 841 identified publications (Figure 1), we were citing 142 selected publications and properly evaluated sixty-nine full-length scientific papers. Further, we used Keywords such as 'climate change,' 'global warming' 'climate change effect' 'climate change hazards,' 'climate change events,' 'heat stress,' 'agricultural workers health in extreme events,' 'agricultural outdoor workers health,' 'work-related health and safety,' 'agricultural workers productivity' etc. during the searching of relevant previous publication.

\section{Systematic analysis of selected studies}

For the Systematic analysis of selected studies, we categorized the reviewed data into six divisions: author name, Objective Study, Study inhabitants, Learning theme, Study Involvement, etc. Table 1 shows a complete summary of a systematic review of 69 fulllength scientific publications. Apart from, we review the climate change effect related scientific study of India, Saudi Arabia, Ghana, Germany, Bangladesh, South Africa, China, USA, Pakistan, Australia, Italy, Costa Rica, Ethiopia, etc. countries and finally concentrated on south Asia's developing countries to achieve our objectives.

\section{Results and Discussion}

We have systematically reviewed one hundred forty-two publications, including full-length papers, books, and websites from 1996 to 2020, where $16 \%$ publications from 1994 to 2009 and $84 \%$ publications from 2010 to 2020. Out of one hundred forty-two citing publications, we properly evaluate sixty-nine full-length scientific papers where $69 \%$ of analysed documents are associated with climate change effect on typical indoor/outdoor workers and public health and adaptation strategies. Around $20 \%$ of analyzed papers are focus on climate change impact on the outdoor men /women agricultural workers, approaches for assessing the effects of heat stress, and prevention strategies. The rest of the analyzed papers are associated with workers related to construction, mining, brick industries, steel industries, etc., on the same topic. Apart from, we review the climate change effect related scientific study of India, Saudi Arabia, Ghana, 
Germany, Bangladesh, South Africa, China, USA, Pakistan, Australia, Italy, Costa Rica, Ethiopia, etc. countries and finally concentrated on south Asia's developing countries to achieve our objectives Further, from the selected suitable papers, we have mainly focused on climate change effect, occupational hazards due to climate change events, agricultural workers health, approaches for assessing the heat stress, productivity, and adaptation.

In the present study review 142 published documents to abstract data for the following objectives that include to evaluate the effect of climate change-related events on agricultural workers. To highlight the approaches for assessing the heat stress on agricultural workers. And also to highlight some of the protection approaches for agricultural workers to mitigate the effect of climate change.

The principle review tropic of the analysis papers is to identify the effect of climate change on agricultural workers' health. To accesses this issue due to limited evidence related to the agricultural sector, we also review some similar tropics on common public health effects, assessing the impact of heat stress and decrease productivity due to climate change. In this review paper, we also reviewed the adaptation strategies for the common public and workers. Finally, we highlighted the essential prevention strategies to mitigate the effect of climate change on agricultural workers.

\section{Effect of climate change related hazards on agricultural workers}

Increased temperature, changes in precipitation, increased air pollution, more extensive flooding, enhanced drought, heatwaves, the extent of vector-borne disease, and other climate change-related hazards are significantly influencing the life of agricultural workers, which affect the productivity of workers (Krishnamurthy et al., 2016;Sadiq et al., 2019). The reduction in productivity will further lead to low income (Nilsson et al., 2010; Lundgren et al., 2012; Xiang et al., 2016; day et al., 2018; Flouris et al., 2018;Kjellstrom et al., 2009 ). This will affect workers' livelihood and, as a result, migration of labor from the agricultural sector to sector (StaalWesterlund, 2018; Sadiq et al., 2019; Ahmed et al., 2019; Day et al., 2018; Moda et al., 2019; Michael Safi, 2017). Swaminathan et al., (2016) exposed that Climate change may have subsidized the suicides of around 60,000 Indian agricultural workers and farmers over the past three decades, which is one of the burning evidence of the influence of climatic variation on agricultural workers in a developing country. Further, the adverse effects of climatic variation on job associated safety and health have already been extensively deliberate on the general population rather than agricultural workers. Following the considerable effects of Climate Change, related hazards on agricultural workers are described below.

\section{Extreme heat}

Global Climatic variation influences the working and living surroundings and generates health threats for the millions of population (IPPC, 2007; Costello, 2009; Kjellstrom et al., 2009). The first concern of Climatic variation is global warming, which directly hurts the biological, physical, and human system by causing many negative impacts (Sustainability Committee, 2018). The average global temperature is increasing, and it is predicted that temperature may increase from 2.5 to $10{ }^{\circ} \mathrm{F}$ at the end next century (IPPC, 2007, Bilbeisi et al., 2017). At extreme levels, heat events become a significant problem for vulnerable agricultural populations as harsh hot environments 
increase the risk of work-related heat illness (Flocks et al., 2013). According to the WHO report, from 2000 to 2016, around 125 million people are exposed to heatwaves, and more than 166000 people died from 1998 to 2017 worldwide from extreme heat exposure..If average ambient temperatures increase, more farmworkers will be exposed to heat-induced disorders, as most agricultural workers are bound to work in hot outdoor environments (Moda et al., 2019; ILO, 2019). Applebaum et al., (2016) noted that heat-associated mortality and mobility risks are most apparent in the agricultural sector. Pogačar et al., (2017) are also exposed in their study that agricultural workers come under the highest impact of heat stress in outdoor working conditions.

Apart from pregnant farmworkers, when they are exposed to a hot environment, they usually face additional health risks (Flocks et al., 2013). Stephen L. McQueen (2012) reported that the heat-related mortality rate in agricultural workers is almost twenty times of other industries. Christopher Walljasper (2019) stated that around $20 \%$ of heat-related deaths narrated by OSHA are in the agricultural, forestry, and fishing sectors.

Further, the "Body temperature" term generally use to ill define. The human body is divided into two sections, which are well recognized as the "shell" and the "core." The "shell" consists of skin, limbs, hypodermal tissues, etc. and the "core" includes by skull, abdomen, thorax, etc. (Cooper, 1996). Because numerous jobs in the agricultural sector are physically demanding, the body of farmers usually produces significant surplus heat. The human body able to perform work when it transforms food into energy, which also makes heat.In the human body, about $75 \%$ of the life in food converted into heat. More power is required to perform more massive work, and hence more heat is produced.

A lesser portion of the heat is used to maintain the inner body temperature at $37{ }^{\circ} \mathrm{C}$. Still, the most significant part of the heat is dissolute into the surroundings by radiation, convection, conduction, and evaporation in the form of sweat. (Staal Wästerlund,2018; Matthew Stevens, 2016;David J. Sailor, 2011). From a thermal comfort point of view, there is a primary need to maintain core body temperature $(\mathrm{CBT})$ close to $37^{\circ} \mathrm{C}\left(98.6^{\circ} \mathrm{F}\right)$. The subtraction of heat produce by metabolic rate and the mechanical work must be balanced with heat lost by our body in the environment to maintain the CBT as close to $37{ }^{\circ} \mathrm{C}$. A combined group of situations such as a hot environment, high humidity, physical exercise, dehydration, and clothing can disturb the equilibrium. However, factors responsible for heat stress in the human body are characterized into six categories, out of which two personal and four environmental. The personal factors are activity, clothing, etc. and environmental factors are relative air velocity, mean radiant temperature, air temperature, air relative humidity, etc. (Acharya et al., 2018; Gubernot et al., 2013; Morioka et al., 2006; Park et al., 2017, Halawa, et al., 2012). Due to this imbalance, the temperature of our core body becomes more than $37{ }^{\circ} \mathrm{C}$, resulting in heat stress (Kjellstrom and Crowe, 2011; Crowe et al., 2009; Adrian et al., 2008; Meg Jenkins, 2019; Fantozzi and Lamberti, 2019). Furthermore, heat stress causes physiological strain, fatigue, and tiredness among workers in many work-related settings where agricultural work plays a prominent role. Heat stress may lead to mild heat disorder to death (Heat stoke) (Tustin et al., 2018; Hanna et al., 2015). Besides symptoms arise by extreme heat and autonomic dissipation mechanisms of our body are generally characterized as heat cramp, heat rash, heat syncope, heat exhaustion, heatstroke, etc. (Jackson and 
Rosenberg, 2010; Kjellstrom et al., 2014; Kilbourne et al., 1997; Wilson et al., 2012; Kovats et al., 2007). Apart from the mention of heat illness, some others direct and indirect effect of extreme heat are chronic kidney disease, enhance work injury, accident risk, increase chronic mental disorder, reduction in physical activity capacity, reduce productivity can be observed in agricultural workers, which are illustrated in Figure 2 ( Varghese et al., 2018; Kiefer et al., 2016; Xiang et al., 2014; Messeri et al., 2019; Huang et al., 2011; Hancock et al., 2003; Sheng et al., 2018). Moreover, high ambient temperature because of climate change may also increase workrelated exposure to hazardous chemicals and harms agricultural workers (Balbus et al., 2013; Boxall et al., 2009).

\section{Extreme weather events}

Climatic variation, global climate change, and a higher frequency of extreme weather events lead to a considerable increase in agricultural risk and decrease farm income. Extreme weather events influence the life of farmworkers and cause an impact on agrarian policymakers (Gobin et al., 2013). On the other hand, extreme weather event causes a tremendous effect on crop yield, which indirectly affect the farmer's income (Powell et al., 2016; Kumar et al., 2014). Levy and Roelofs (2019) mention in their report that many workers, including agricultural workers, are at high risk of work-related hazards from extreme weather events. Extreme weather events such as cyclone, landslides, floods, thunderstorm, lightning strikes, droughts, heat, and cold waves, and wildfires are causes harmful effect on agricultural workers (Handmer et al., 2012; Conforti et al., 2018; Levy and Roelofs, 2019; Schulte et al., 2016; Applebaum et al., 2016; Bouzid et al., 2013; Schulte et al., 2009; Ylipaa et al., 2019; De et al., 2005).
Thrilling climate events extend a diverse safety and health risks such as hit by flying substances, falls and injuries from slips, vector bone disease, inadequate sleep, and nourishment because of long and continuous work shifts, mental Stress, and physical tiredness (WHO, 2018; Kiefer et al., 2016; Levy and Roelofs, 2019). Mahapatra et al., (2018) reported that around five individuals per million died due to exposure to extreme events, which is approximately $25 \%$ of all coincidental death due to natural causes. Prolonged drought and other climateassociate calamities may destroy the economic and social foundation on which agricultural populations are related (Berry et al., 2011). Schulte et al., (2016) noted that extreme weather events force workers to extend work hours and persist at the workplace until substitutes arrive, enhancing mental exhaustion that raises accidental risk. Swaminathan and Rengalakshmi (2016) stated that extreme weather events appear as a prospective hazard to farmer's livelihoods and food security in the circumstance of climate change.

\section{Air pollution}

There are many links between climate change and air quality. A hot climatic condition leads to severe air pollution, particularly with ground-level ozone and delicate particulate matter (FPM) (Fiore et al., 2015; EPA, 2020; Ebi and McGregor, 2008).

Climate change also influences air quality by changing rainfall patterns, air composition, atmospheric interaction, anthropogenic and natural sources, which are responsible for air pollution (Fann et al., 2016; Fiore et al., 2015). 
Table.1 Systematic analysis of scientific papers for review (Adopted and revised from Moda et al., s2019)

\begin{tabular}{|c|c|c|c|c|c|c|}
\hline $\begin{array}{l}\text { Sl. } \\
\text { No. }\end{array}$ & $\begin{array}{l}\text { Author and } \\
\text { Year }\end{array}$ & ObjectiveStudy & $\begin{array}{l}\text { Study } \\
\text { Inhabitants }\end{array}$ & Learning Theme & Study Involvement & Outcome Data and Study Measure \\
\hline 1 & $\begin{array}{l}\text { Schulte } \text { et al., } \\
\text { (2016) }\end{array}$ & $\begin{array}{l}\text { Improvement of anoutlineto the } \\
\text { recognition of climaticvariationeffect on } \\
\text { workers and work-related safety and } \\
\text { health }\end{array}$ & Mutual worker & $\begin{array}{l}\text { Extreme weather events, work- } \\
\text { related safety and health, risk } \\
\text { assessment and management }\end{array}$ & $\begin{array}{l}\text { Determination of interactions among } \\
\text { work hazards, climate, and other } \\
\text { influences, assessment of risk by the } \\
\text { hazard of climate change }\end{array}$ & $\begin{array}{l}\text { The practice of lookout effects and foremost pointers to } \\
\text { support the investigation of climate associated } \\
\text { occupational effects and theoretical outline established } \\
\text { to avoiding hostile effects of climate change by risk } \\
\text { assessment }\end{array}$ \\
\hline 2 & $\begin{array}{l}\text { Applebaum } e t \\
\text { al., (2016) }\end{array}$ & $\begin{array}{l}\text { Overview of climate change-related work- } \\
\text { related exposures and its recommendation }\end{array}$ & $\begin{array}{l}\text { Common } \\
\text { workers }\end{array}$ & $\begin{array}{l}\text { Climate change, Work-related } \\
\text { risks, Heat, Polycyclic scented } \\
\text { hydrocarbons, Ozone, } \\
\text { Pathogenic microbes, Vector- } \\
\text { borne diseases, and Violence }\end{array}$ & $\begin{array}{l}\text { Assessment of most vulnerable } \\
\text { occupational sectors due to climate } \\
\text { change } \\
\text { define study required to defend } \\
\text { workers from the projected health } \\
\text { intimidations from climate alteration }\end{array}$ & $\begin{array}{l}\text { Suggestions for forestalling about most susceptible } \\
\text { workers due to climate change and demonstrating } \\
\text { situations concentrating on work-related impacts of } \\
\text { extreme climate events and its extenuation. }\end{array}$ \\
\hline 3 & $\begin{array}{l}\text { Crowe et al., } \\
(2009)\end{array}$ & $\begin{array}{l}\text { An experimental, qualitative field } \\
\text { assessment on occupational heat stress in } \\
\text { sugarcane workforces }\end{array}$ & $\begin{array}{l}\text { Sugarcane } \\
\text { workers } \\
\text { Costa Rica }\end{array}$ & $\begin{array}{l}\text { Climate alteration, Costa Rica, } \\
\text { heat contact, heat stress, and } \\
\text { sugarcane workers }\end{array}$ & $\begin{array}{l}\text { Plan to improve the health and safety } \\
\text { of sugarcane workers from heat } \\
\text { influences }\end{array}$ & $\begin{array}{l}\text { Improve understanding of various factors that help to } \\
\text { increase sugarcane workers health and safety }\end{array}$ \\
\hline 4 & $\begin{array}{l}\text { Deressa et al., } \\
(2010)\end{array}$ & $\begin{array}{l}\text { Identify the farmer's awareness of Climate } \\
\text { Change and Prevention to mitigate climate } \\
\text { change }\end{array}$ & $\begin{array}{l}\text { Farmers of } \\
\text { Ethiopia }\end{array}$ & $\begin{array}{l}\text { Climate Change, Farmer, Nile } \\
\text { basin of Ethiopia, Perception of } \\
\text { Climate Alteration and } \\
\text { Adaptation }\end{array}$ & $\begin{array}{l}\text { Identify and mitigation of the effect } \\
\text { of climate alteration on } \\
\text { agriculturalists }\end{array}$ & $\begin{array}{l}\text { Define how agriculturalists canminimize the harmful } \\
\text { effect of climate change }\end{array}$ \\
\hline 5 & $\begin{array}{l}\text { Fang et al., } \\
(2013)\end{array}$ & $\begin{array}{l}\text { Relationship between climate alteration } \\
\text { and air chemistry affects atmospheric } \\
\text { configuration and human death related to } \\
\text { increasing air pollution by industry. }\end{array}$ & population & $\begin{array}{l}\text { Climate change, Methane } \\
\text { concentration, Fine particulate } \\
\text { matter and ozone, Air } \\
\text { pollution, Human mortality }\end{array}$ & $\begin{array}{l}\text { Identify how increasing delicate } \\
\text { particle matter, ozone, methane } \\
\text { responsible for human mortality }\end{array}$ & $\begin{array}{l}\text { Explain the relation between climacteric variation and } \\
\text { air pollution, its impact on air quality and health of the } \\
\text { population, and the measure to air pollution control } \\
\text { policy by methane mitigation. }\end{array}$ \\
\hline 6 & $\begin{array}{l}\text { Sherwood et } \\
\text { al., } \\
(2010)\end{array}$ & $\begin{array}{l}\text { Find the Survivability limit of the general } \\
\text { population in heat stress for climate } \\
\text { change }\end{array}$ & $\begin{array}{l}\text { General } \\
\text { population }\end{array}$ & $\begin{array}{lr}\text { Paleoclimate, Climate } & \text { change, } \\
\text { Global Warming, } & \text { Climate } \\
\text { impact, WBGT, } & \text { Human } \\
\text { Physiology } & \end{array}$ & $\begin{array}{l}\text { Define human adaptableness limit to } \\
\text { mitigate the effect of climate } \\
\text { alteration }\end{array}$ & $\begin{array}{l}\text { Identify heat stress, and it used to clarify trends in the } \\
\text { human fossil record }\end{array}$ \\
\hline 7 & $\begin{array}{l}\text { Varghese } e t \\
\text { al., (2018) }\end{array}$ & $\begin{array}{l}\text { Observe the association between heat } \\
\text { contract and occupational injuries }\end{array}$ & $\begin{array}{l}\text { Common } \\
\text { workers }\end{array}$ & $\begin{array}{l}\text { Climate alteration Increasing } \\
\text { Temperature, Heat exposure, } \\
\text { heat stress, and Occupational } \\
\text { hurts }\end{array}$ & $\begin{array}{l}\text { Heat exposure and Occupational } \\
\text { injuries }\end{array}$ & $\begin{array}{l}\text { Deliver suitable proposal for policy and research } \\
\text { direction to reduce occupational injuries }\end{array}$ \\
\hline 8 & $\begin{array}{l}\text { Jackson et al., } \\
(2010)\end{array}$ & $\begin{array}{l}\text { Reduction of heat-related Illness of } \\
\text { agricultural workers by proper prevention } \\
\text { measures }\end{array}$ & $\begin{array}{l}\text { Agricultural } \\
\text { workers }\end{array}$ & $\begin{array}{l}\text { Agricultural workers, } \\
\text { Occupational heat stress, heat- } \\
\text { related Illness, hyperthermia, } \\
\text { acclimatization and Prevention }\end{array}$ & $\begin{array}{l}\text { Heat-related illness and prevention } \\
\text { measure }\end{array}$ & $\begin{array}{l}\text { Help to understand the heat-related illness of farmers } \\
\text { and promote proper Prevention }\end{array}$ \\
\hline 9 & $\begin{array}{l}\text { Acharya } e t \\
\text { al., (2018) }\end{array}$ & $\begin{array}{l}\text { Assessing the harshness of heat stress that } \\
\text { influence the construction workers and } \\
\text { efforts in applying preventive measures. }\end{array}$ & $\begin{array}{l}\text { building } \\
\text { workers }\end{array}$ & $\begin{array}{l}\text { Climate alternation, elevated } \\
\text { temperature, construction } \\
\text { workers, heat stress, heat- } \\
\text { related illness, and Prevention } \\
\text { measure. }\end{array}$ & $\begin{array}{l}\text { Heath of construction workers in } \\
\text { changing climate }\end{array}$ & $\begin{array}{l}\text { Identify the risk factor of heat stress in construction } \\
\text { works and its preventive measure }\end{array}$ \\
\hline
\end{tabular}




\begin{tabular}{|c|c|c|c|c|c|c|}
\hline \multicolumn{7}{|c|}{ Continuation of Table 1} \\
\hline $\begin{array}{l}\text { Sl. } \\
\text { No. }\end{array}$ & $\begin{array}{l}\text { Author and } \\
\text { Year }\end{array}$ & Objective Study & $\begin{array}{l}\text { Study } \\
\text { Inhabitants }\end{array}$ & Learning Theme & Study Involvement & Outcome Data and Study Measure \\
\hline 10 & $\begin{array}{l}\text { Al- } \\
\text { Bouwarthan } \\
\text { et al., (2019) }\end{array}$ & $\begin{array}{l}\text { Measure heat stress among construction } \\
\text { workers with the help of WBGT and } \\
\text { define the work factor associated with heat } \\
\text { stress and parameter for managing heat } \\
\text { stress. }\end{array}$ & $\begin{array}{l}\text { construction } \\
\text { worker }\end{array}$ & $\begin{array}{l}\text { Excessive heat, construction } \\
\text { workers, heat exposure, } \\
\text { intensity and duration of heat } \\
\text { stress, WBGT, and protective } \\
\text { measures }\end{array}$ & $\begin{array}{l}\text { Measurement of heat stress of } \\
\text { construction workers with the help of } \\
\text { the WBGT index and define } \\
\text { protective measures }\end{array}$ & $\begin{array}{l}\text { Identify the severity of heat stress and its influence on } \\
\text { construction workers and improve work-related heat } \\
\text { stress experience strategies in S.A. }\end{array}$ \\
\hline 11 & $\begin{array}{l}\text { Moda et al., } \\
\text { (2019) }\end{array}$ & $\begin{array}{l}\text { Evaluation of the primary and secondary } \\
\text { consequence of extreme heat and its safety } \\
\text { measure for outdoor workers }\end{array}$ & Outdoor worker & $\begin{array}{l}\text { Climate change, high } \\
\text { temperature, outdoor workers, } \\
\text { direct and indirect impact, } \\
\text { prevention measure }\end{array}$ & $\begin{array}{l}\text { Heat stress on outdoor workers and } \\
\text { its prevention strategies }\end{array}$ & $\begin{array}{l}\text { Reveal the urgent need for research on health and } \\
\text { financial influences of climate change in the developing } \\
\text { country and define safety measure of outdoor workers } \\
\text { against extreme heat }\end{array}$ \\
\hline 12 & $\begin{array}{l}\text { Srinivasan et } \\
\text { al.,(2016) }\end{array}$ & $\begin{array}{l}\text { Describe the Sign of work-related heat } \\
\text { stress and its health effects }\end{array}$ & $\begin{array}{l}\text { General work } \\
\text { Population of } \\
\text { India }\end{array}$ & $\begin{array}{l}\text { Work-related heat stress, India, } \\
\text { Core body temperature, health } \\
\text { impact, and Prevention } \\
\text { measure }\end{array}$ & $\begin{array}{l}\text { Contests and Prevention measure of } \\
\text { job-related heat anxiety }\end{array}$ & $\begin{array}{l}\text { Suggest the Prevention measure to mitigating the } \\
\text { effects of too much heat on workforces heath }\end{array}$ \\
\hline 13 & $\begin{array}{l}\text { Kjellstrom et } \\
\text { al., (2009) }\end{array}$ & $\begin{array}{l}\text { Measure the possible consequence of heat } \\
\text { for climate variation on workers' health } \\
\text { and productivity. }\end{array}$ & $\begin{array}{l}\text { the population } \\
\text { of middle and } \\
\text { low-income } \\
\text { country }\end{array}$ & $\begin{array}{l}\text { Global climatic variation, } \\
\text { temperature elevation, heat } \\
\text { exposure, WBGT, core body } \\
\text { temperature, and work capacity }\end{array}$ & $\begin{array}{l}\text { A consequence of job associated } \\
\text { hotness anxiety on workers' physical } \\
\text { health and output }\end{array}$ & $\begin{array}{l}\text { Highlight the relationship between working capacity } \\
\text { and WBGT and the negative effect of climate change } \\
\text { on worker productivity and heat-related social and } \\
\text { economic development measures. }\end{array}$ \\
\hline 14 & $\begin{array}{l}\text { Xiang et al., } \\
(2016)\end{array}$ & $\begin{array}{l}\text { To examine workers' observations and } \\
\text { communicative replies to extreme heat } \\
\text { contract and recognize individuals' } \\
\text { warmness observations factors }\end{array}$ & $\begin{array}{l}\text { South } \\
\text { Australian } \\
\text { typical workers }\end{array}$ & $\begin{array}{l}\text { Occupational heat exposure, } \\
\text { heat stress, heat illness, } \\
\text { Occupational injuries, } \\
\text { observations, risk awareness, } \\
\text { and prevention strategies. }\end{array}$ & $\begin{array}{l}\text { Inspect workers' response and } \\
\text { perception in extreme heat. }\end{array}$ & $\begin{array}{l}\text { Highlighted the needs to strengthen workers' by proper } \\
\text { training in extreme heat, improve prevention strategies, } \\
\text { and promotion of educational training }\end{array}$ \\
\hline 15 & $\begin{array}{l}\text { Flouris et al., } \\
(2018)\end{array}$ & $\begin{array}{l}\text { Assessment of heat strain effect on } \\
\text { workers productivity and health }\end{array}$ & $\begin{array}{l}\text { Common } \\
\text { workers }\end{array}$ & $\begin{array}{l}\text { Work-related heat strain, } \\
\text { workers' health, productivity, } \\
\text { PRISMA guidelines, statistical } \\
\text { models, and heat stress } \\
\text { mitigation. }\end{array}$ & $\begin{array}{l}\text { A consequence of heat anxiety on } \\
\text { workers' healthiness and output }\end{array}$ & $\begin{array}{l}\text { Exposed heat stress affected workers' health and work } \\
\text { productivity, Suggest the need for international action } \\
\text { to mitigate climate change. }\end{array}$ \\
\hline 16 & $\begin{array}{l}\text { Kiefer et al., } \\
(2016)\end{array}$ & $\begin{array}{l}\text { Recapitulates and deliberates the effect of } \\
\text { climatic variation on American workforces } \\
\text { healthiness and wellbeing }\end{array}$ & $\begin{array}{l}\text { American } \\
\text { workers }\end{array}$ & $\begin{array}{l}\text { Climate change, work-related } \\
\text { heat exposure, work-related } \\
\text { hazards, America's worker, heat } \\
\text { illness, workers health, and } \\
\text { safety }\end{array}$ & $\begin{array}{l}\text { Effect of climate change on workers } \\
\text { heath }\end{array}$ & $\begin{array}{l}\text { Provides strong evidence of the effect of climate change } \\
\text { on workers and prevention strategies }\end{array}$ \\
\hline 17 & $\begin{array}{l}\text { Orru et al., } \\
(2017)\end{array}$ & $\begin{array}{l}\text { Assessment of current indication on the } \\
\text { consequence of climaticvariation on air } \\
\text { contamination and its health outcome }\end{array}$ & $\begin{array}{l}\text { General } \\
\text { Population }\end{array}$ & $\begin{array}{l}\text { Climatic variation, air } \\
\text { pollution, particulate } \\
\text { matter,ozone,emission, } \\
\text { Spreading, and health impact }\end{array}$ & $\begin{array}{l}\text { Air pollution and Climatic variation } \\
\text { effect on population wellbeing }\end{array}$ & $\begin{array}{l}\text { Discovers the associations among climate alteration, air } \\
\text { contamination, and air contamination associated with } \\
\text { health effects and predicts the future air pollution } \\
\text { emission. }\end{array}$ \\
\hline
\end{tabular}




\begin{tabular}{|c|c|c|c|c|c|c|}
\hline \multicolumn{7}{|c|}{ Continuation of Table 1} \\
\hline $\begin{array}{l}\text { Sl. } \\
\text { No. }\end{array}$ & $\begin{array}{l}\text { Author and } \\
\text { Year }\end{array}$ & ObjectiveStudy & $\begin{array}{l}\text { Study } \\
\text { Inhabitants }\end{array}$ & Learning Theme & Study Involvement & Outcome Data and Study Measure \\
\hline 18 & $\begin{array}{l}\text { Xiang et al., } \\
(2014)\end{array}$ & $\begin{array}{l}\text { Inspect the effect of heat waves on } \\
\text { worker's safety and health, injuries and } \\
\text { illnesses from heat waves }\end{array}$ & $\begin{array}{l}\text { South } \\
\text { Australian } \\
\text { workers' }\end{array}$ & $\begin{array}{l}\text { Climate change, heatwave, } \\
\text { South Australian workers', } \\
\text { work-related health, injuries, } \\
\text { adaptation and Prevention }\end{array}$ & $\begin{array}{l}\text { Effect of heatwaves on worker's } \\
\text { health and safety }\end{array}$ & $\begin{array}{l}\text { Identify the occupational illness associated with } \\
\text { heatwaves and provides a measure for adaptation and } \\
\text { Prevention from heatwaves }\end{array}$ \\
\hline 19 & $\begin{array}{l}\text { Laaidi et al., } \\
\text { (2011) }\end{array}$ & $\begin{array}{l}\text { Evaluation of research gap associated with } \\
\text { work-related heat and research need to } \\
\text { overcome assessment heat disorders }\end{array}$ & $\begin{array}{l}\text { Common U.S. } \\
\text { worker }\end{array}$ & $\begin{array}{l}\text { Climate change, U.S. worker, } \\
\text { heat exposure, occupational } \\
\text { heat, heat illness, adaptation, } \\
\text { and Prevention }\end{array}$ & $\begin{array}{l}\text { Epidemiology of work-related heat } \\
\text { contact and prevention strategies }\end{array}$ & $\begin{array}{l}\text { Identify the research gap on work-related heat exposure } \\
\text { and Making policy for Prevention from work-related } \\
\text { heat }\end{array}$ \\
\hline 20 & $\begin{array}{l}\text { Gubernot } e t \\
\text { al., (2013) }\end{array}$ & $\begin{array}{l}\text { Review of high-temperature illness for } \\
\text { job-related heat contact and prevention } \\
\text { approaches }\end{array}$ & $\begin{array}{l}\text { population of } \\
\text { U.S. }\end{array}$ & $\begin{array}{l}\text { The United States, climate } \\
\text { change, heat exposure, } \\
\text { workplace hazard, risk, heat- } \\
\text { related illness and death, } \\
\text { adaptation and Prevention } \\
\text { strategies }\end{array}$ & $\begin{array}{l}\text { Health hazardfor work-related heat } \\
\text { contact and its prevention policy }\end{array}$ & $\begin{array}{l}\text { Highlight the risk factors due to heat exposure and } \\
\text { suggest adaptation strategies }\end{array}$ \\
\hline 21 & $\begin{array}{l}\text { Kjellstrom et } \\
\text { al., (2013) }\end{array}$ & $\begin{array}{l}\text { To observe the physiological indication } \\
\text { due to heat effect, climate strategies for } \\
\text { suitable work environments, and evaluate } \\
\text { the influence of future climacteric } \\
\text { scenarios on workers' productivity. }\end{array}$ & Regional labor & $\begin{array}{l}\text { Global climate change, heat } \\
\text { load, indoor and outdoor } \\
\text { worker, heat effect on health, } \\
\text { climate modeling, and labor } \\
\text { productivity }\end{array}$ & $\begin{array}{l}\text { the straight impression of climatic } \\
\text { variation on regional workers output }\end{array}$ & $\begin{array}{l}\text { Evaluate the loss of working capacity and measure the } \\
\text { need for Prevention from heat exposure }\end{array}$ \\
\hline 22 & $\begin{array}{l}\text { Singh } \text { et al., } \\
(2018)\end{array}$ & $\begin{array}{l}\text { Identify different research on heat stress of } \\
\text { farmers and preventing measure }\end{array}$ & Farmers & $\begin{array}{l}\text { Farmers, hot weather, heat } \\
\text { stress, WBGT, core body } \\
\text { temperature,heart rate, B.P., } \\
\text { and Prevention measure }\end{array}$ & $\begin{array}{l}\text { Effect of heat stress on farmer and } \\
\text { Prevention measure }\end{array}$ & $\begin{array}{l}\text { Evaluation of heat stress by WBGT index and its effect } \\
\text { on farmers body and discuss the significant measure to } \\
\text { minimize heat stress }\end{array}$ \\
\hline 23 & $\begin{array}{l}\text { Nunfam } e t \\
\text { al., (2018) }\end{array}$ & $\begin{array}{l}\text { Evaluation of Consciousness and identify } \\
\text { Community impressions of job-related } \\
\text { heat anxiety, and suitable prevention } \\
\text { measure }\end{array}$ & $\begin{array}{l}\text { Common } \\
\text { workers }\end{array}$ & $\begin{array}{l}\text { Climate alteration, work-related } \\
\text { heat anxiety, healthiness, } \\
\text { safety, andprevention }\end{array}$ & $\begin{array}{l}\text { Communal influences of work-related } \\
\text { heat anxiety and suitable prevention } \\
\text { policy }\end{array}$ & $\begin{array}{l}\text { Describe the awareness of labors in work-related heat } \\
\text { stress, the communal effect of heat anxiety, and } \\
\text { prevention measure of heat stress }\end{array}$ \\
\hline 24 & Fisk (2018) & $\begin{array}{l}\text { Review the probable health concerns in } \\
\text { indoor climate due to climate change }\end{array}$ & $\begin{array}{l}\text { Indoor } \\
\text { residential } \\
\text { people }\end{array}$ & $\begin{array}{l}\text { Indoor residential environment, } \\
\text { climatic variation, inside air } \\
\text { freshness, and health }\end{array}$ & $\begin{array}{l}\text { Effect of climaticvariation on inside } \\
\text { residential setting and human health }\end{array}$ & $\begin{array}{l}\text { Identify health problem in indoor climate due to } \\
\text { climate change and provides a protective measure of } \\
\text { indoor temperature for human health }\end{array}$ \\
\hline 25 & $\begin{array}{l}\text { Rasanen } e t \\
\text { al., (2016) }\end{array}$ & $\begin{array}{l}\text { Review of climate change literature to } \\
\text { examine how multiple stressors of climate } \\
\text { change or non -climate change affect } \\
\text { human vulnerability }\end{array}$ & $\begin{array}{l}\text { General } \\
\text { Population }\end{array}$ & 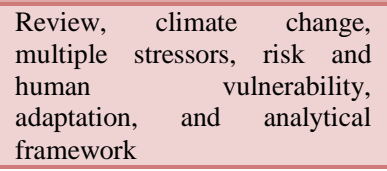 & $\begin{array}{l}\text { Multiple interacting stressors of } \\
\text { climate change or non-climate change } \\
\text { and adaptation policy }\end{array}$ & $\begin{array}{l}\text { Measure the social context of Susceptibility within } \\
\text { literature associated with climate change and suggest } \\
\text { future analytical frameworks of dissimilarities between } \\
\text { different types of stressors and adaptation policy }\end{array}$ \\
\hline
\end{tabular}




\begin{tabular}{|c|c|c|c|c|c|c|}
\hline \multicolumn{7}{|c|}{ Continuation of Table 1} \\
\hline $\begin{array}{l}\text { Sl. } \\
\text { No. }\end{array}$ & $\begin{array}{l}\text { Author and } \\
\text { Year }\end{array}$ & ObjectiveStudy & $\begin{array}{l}\text { Study } \\
\text { Inhabitants }\end{array}$ & Learning Theme & Study Involvement & Outcome Data and Study Measure \\
\hline 26 & $\begin{array}{l}\text { Krishnamurth } \\
\text { y et al., } \\
(2016)\end{array}$ & $\begin{array}{l}\text { A consequence of job-related heat anxiety } \\
\text { on steel industry workers healthiness and } \\
\text { output due to ambient temperature }\end{array}$ & $\begin{array}{l}\text { Work } \\
\text { population of } \\
\text { the steel } \\
\text { industry }\end{array}$ & $\begin{array}{l}\text { The steel industry, ambient } \\
\text { temperature, WBGT, } \\
\text { dehydration, heat-related } \\
\text { illness, productivity loss, and } \\
\text { Prevention policy }\end{array}$ & $\begin{array}{l}\text { Assessment of productivity loss due to } \\
\text { heat stress in the steel industry and } \\
\text { Prevention policy }\end{array}$ & $\begin{array}{l}\text { Productivity loss of workers in steel industries due to } \\
\text { occupational heat exposure and suggest suitable } \\
\text { protective policies }\end{array}$ \\
\hline 27 & $\begin{array}{l}\text { Yazd et al., } \\
\text { (2019) }\end{array}$ & $\begin{array}{l}\text { Review of literature of risk factor } \\
\text { associated with farmer's mental health }\end{array}$ & Farmers & $\begin{array}{l}\text { A systematic review, PRISMA } \\
\text { guidelines, Farmers' mental } \\
\text { health, mental disorder, } \\
\text { farming stress, and mitigation } \\
\text { policy }\end{array}$ & Mental stress factor of farmers & $\begin{array}{l}\text { Describe farmers mental health risk factory, reduction } \\
\text { strategy, and further research }\end{array}$ \\
\hline 28 & $\begin{array}{l}\text { Cianconi } e t \\
\text { al., (2020) }\end{array}$ & $\begin{array}{l}\text { Review of the consequence of climate on } \\
\text { the mental fitness of people }\end{array}$ & $\begin{array}{l}\text { Common } \\
\text { population }\end{array}$ & $\begin{array}{l}\text { A systematic review, climate } \\
\text { change, mental health, mental } \\
\begin{array}{l}\text { disorder, } \\
\text { adaptations }\end{array}\end{array}$ & $\begin{array}{l}\text { Relationship between climate change } \\
\text { and mental health }\end{array}$ & $\begin{array}{l}\text { Identify major mental disorder due to climate change } \\
\text { and psychological adaptations }\end{array}$ \\
\hline 29 & $\begin{array}{l}\text { Balbus et al., } \\
(2012)\end{array}$ & $\begin{array}{l}\text { Connotation among climate change, } \\
\text { chemical blowout, and probable hazard to } \\
\text { health }\end{array}$ & $\begin{array}{l}\text { General } \\
\text { Population }\end{array}$ & $\begin{array}{l}\text { Worldwide climate } \\
\text { pollutants, chemical spread, } \\
\text { Risk valuation, and } \\
\text { Susceptibility }\end{array}$ & $\begin{array}{l}\text { Effect of worldwide climate change to } \\
\text { change the degree of human exposure } \\
\text { to chemical and probable health effect }\end{array}$ & $\begin{array}{l}\text { Determination of better facts to define human contact } \\
\text { to the chemical atmosphere relatedto climaticvariation }\end{array}$ \\
\hline 30 & $\begin{array}{l}\text { Sadiq et al., } \\
\text { (2019) }\end{array}$ & $\begin{array}{l}\text { Evolution of climatic variation effect on } \\
\text { maize farmer's fitness and output }\end{array}$ & Maize Farmer & $\begin{array}{l}\text { Heat stress, maize farmers } \\
\text { health, WBGT, heat stress } \\
\text { disorders, and Productivity }\end{array}$ & $\begin{array}{l}\text { Evaluation of heat stress disorder and } \\
\text { productivity of maize farmers }\end{array}$ & $\begin{array}{l}\text { Highlight the heat stress disorder and predict } \\
\text { productivity loss of maize farmers }\end{array}$ \\
\hline 31 & $\begin{array}{l}\text { Sadiq et al., } \\
\text { (2019) }\end{array}$ & $\begin{array}{l}\text { Evaluation of the farming community to } \\
\text { identify the change of the vulnerability } \\
\text { index of farmers }\end{array}$ & Farmer & $\begin{array}{l}\text { Climate change, } \\
\text { related hazards } \\
\text { physiological } \\
\text { farmers, } \\
\text { vulnerability, and } \\
\text { strategies }\end{array}$ & $\begin{array}{l}\text { Effect of climate change on the } \\
\text { vulnerability of farmers }\end{array}$ & $\begin{array}{l}\text { Vulnerable factors of farmers from climate change and } \\
\text { suggest adaptation strategies }\end{array}$ \\
\hline 32 & $\begin{array}{l}\text { Kiefer et al., } \\
(2017)\end{array}$ & $\begin{array}{l}\text { Assessment of workers healthiness and } \\
\text { hazard from the climatic variation }\end{array}$ & $\begin{array}{l}\text { Common } \\
\text { worker } \\
\text { America }\end{array}$ & $\begin{array}{l}\text { Impact of climate change, heat } \\
\text { exposure, work-related risk, } \\
\text { American workers health, } \\
\text { illness, occupational safety, and } \\
\text { health, }\end{array}$ & $\begin{array}{l}\text { Assessment hazards, surveillance, and } \\
\text { risk arising from climate change }\end{array}$ & $\begin{array}{l}\text { Highlight the hazard and risk arose from climate change } \\
\text { in American workers and research requirement }\end{array}$ \\
\hline 33 & $\begin{array}{l}\text { Morioka } e t \\
\text { al., (2006) }\end{array}$ & $\begin{array}{l}\text { Evaluation of hot atmosphere ata building } \\
\text { site in hot season and its effects on the } \\
\text { health of workers. }\end{array}$ & $\begin{array}{l}\text { Workers at } \\
\text { Construction } \\
\text { Site }\end{array}$ & $\begin{array}{l}\text { Hot surroundings, Construction } \\
\text { site, outdoor work condition, } \\
\text { health hazard, Prevention } \\
\text { Measures and control }\end{array}$ & $\begin{array}{l}\text { Measurement of serum osmotic } \\
\text { pressure and other health-associated } \\
\text { effects such as blood chemical data } \\
\text { (blood sugar, blood urea nitrogen, } \\
\text { etc.) }\end{array}$ & $\begin{array}{l}\text { Precautionary heat anxietymethods, for example, } \\
\text { passable aeration, edible water, drinks containing salt, } \\
\text { break, health education and training }\end{array}$ \\
\hline
\end{tabular}




\begin{tabular}{|c|c|c|c|c|c|c|}
\hline \multicolumn{7}{|c|}{ Continuation of Table 1} \\
\hline $\begin{array}{l}\text { Sl. } \\
\text { No. }\end{array}$ & $\begin{array}{l}\text { Author and } \\
\quad \text { Year }\end{array}$ & Objective Study & $\begin{array}{l}\text { Study } \\
\text { Inhabitants }\end{array}$ & Learning Theme & Study Involvement & Outcome Data and Study Measure \\
\hline 34 & $\begin{array}{l}\text { Messeri et al., } \\
\text { (2019) }\end{array}$ & $\begin{array}{l}\text { Evaluation of the consequence of } \\
\text { warmness anxiety on agricultural and } \\
\text { construction sector workers and describe } \\
\text { local and migrant workers' awareness and } \\
\text { management. }\end{array}$ & $\begin{array}{l}\text { Native and } \\
\text { migrant worker }\end{array}$ & $\begin{array}{l}\text { Climate challenges, the native } \\
\text { and migrant worker, } \\
\text { construction and agricultural } \\
\text { sector, heatwave, WBGT, } \\
\text { occupational hazard, and } \\
\text { productivity }\end{array}$ & $\begin{array}{l}\text { Observation of heat risk in a } \\
\text { workplace among native and migrant } \\
\text { workers of the agricultural and } \\
\text { construction sector }\end{array}$ & $\begin{array}{l}\text { Identify behavior differences on heat stress awareness } \\
\text { and prevention strategies to the mitigation of heat stress }\end{array}$ \\
\hline 35 & $\begin{array}{l}\text { Xiang et al., } \\
(2013)\end{array}$ & $\begin{array}{l}\text { Review of the consequence characteristics } \\
\text { of job-related heat exposure on workers } \\
\text { fitness and mitigation strategy }\end{array}$ & $\begin{array}{l}\text { Workers from } \\
\text { different sector }\end{array}$ & $\begin{array}{l}\text { Extreme heat, climatic } \\
\text { variation, job-related heat } \\
\text { contact, risk, heart disorder, } \\
\text { and prevention strategies }\end{array}$ & $\begin{array}{l}\text { Characteristics of workers health in } \\
\text { extreme heat and adaptation policy }\end{array}$ & $\begin{array}{l}\text { Deliberate occupational risk due to work-related heat } \\
\text { exposure of different sector workers and suggest future } \\
\text { research needs }\end{array}$ \\
\hline 36 & $\begin{array}{l}\text { Flocks et al., } \\
\text { (2014) }\end{array}$ & $\begin{array}{l}\text { Measure risk factors, work practices, and } \\
\text { awareness of heat-related illness of female } \\
\text { farmworkers in hot environments }\end{array}$ & $\begin{array}{l}\text { Female } \\
\text { farmworkers }\end{array}$ & $\begin{array}{l}\text { Female farmworkers, extreme } \\
\text { heat, heat-related illness, } \\
\text { awareness, and pregnancy } \\
\text { health }\end{array}$ & $\begin{array}{l}\text { Heat effect on the health of pregnant } \\
\text { female workers and their } \\
\text { Consciousness }\end{array}$ & $\begin{array}{l}\text { Expose heat-related fitness of female pregnant women } \\
\text { and suggest protection and prevention strategies }\end{array}$ \\
\hline 37 & $\begin{array}{l}\text { Thomas et al., } \\
\text { (2014) }\end{array}$ & $\begin{array}{l}\text { Greater insight into the consequence of } \\
\text { climatic variation on human health }\end{array}$ & $\begin{array}{l}\text { Common } \\
\text { population }\end{array}$ & $\begin{array}{l}\text { Anthropogenic climate change, } \\
\text { health-related impact, health, } \\
\text { mitigation, and happiness }\end{array}$ & $\begin{array}{l}\text { Understanding of the health-related } \\
\text { effect of climate change with Greater } \\
\text { insight }\end{array}$ & $\begin{array}{l}\text { Suggest mitigation strategies of climate change effect } \\
\text { on health and future adaptation policies }\end{array}$ \\
\hline 38 & $\begin{array}{l}\text { Lucas et al., } \\
(2014)\end{array}$ & $\begin{array}{l}\text { Evaluation of current and future risk in } \\
\text { work-related heat exposure with } \\
\text { ergonomic intervention }\end{array}$ & $\begin{array}{l}\text { Common } \\
\text { workers }\end{array}$ & $\begin{array}{l}\text { work-related heat exposure, } \\
\text { heat stress, ergonomics, and } \\
\text { work-related injury }\end{array}$ & $\begin{array}{l}\text { Controlling of heat strain and } \\
\text { Mitigation of heat illness }\end{array}$ & $\begin{array}{l}\text { Compulsory protection need to mitigate the effect of } \\
\text { extreme heat exposure and make sure clothing } \\
\text { possessions and knowledge of thermoregulation and } \\
\text { proper management }\end{array}$ \\
\hline 39 & $\begin{array}{l}\text { Sett et al., } \\
(2018)\end{array}$ & $\begin{array}{l}\text { Assessment of the impact of heat on } \\
\text { work-related heat exposure female brick } \\
\text { workers and their productivity }\end{array}$ & $\begin{array}{l}\text { Female brick } \\
\text { worker of India } \\
\text { (West Bengal) }\end{array}$ & $\begin{array}{l}\text { Female brick workers, extreme } \\
\text { heat, cardiac strain, WBGT, } \\
\text { productivity, and cropping } \\
\text { strategy }\end{array}$ & $\begin{array}{l}\text { Heat stress on female brick workers, } \\
\text { their productivity, and cropping } \\
\text { strategy }\end{array}$ & $\begin{array}{l}\text { Productivity loss with temperature and provides some } \\
\text { adaptation strategies such as regular fluid intake, slow } \\
\text { working, rearranging of the work-rest cycle, and inspire } \\
\text { ergonomic involvements }\end{array}$ \\
\hline 40 & $\begin{array}{l}\text { Lundgren } e t \\
\text { al., (2012) }\end{array}$ & $\begin{array}{l}\text { Evaluation of heat anxiety influences on } \\
\text { workers for climatic variation }\end{array}$ & $\begin{array}{l}\text { Work } \\
\text { population of } \\
\text { Developing } \\
\text { countries }\end{array}$ & $\begin{array}{l}\text { Changing climate, heat stress, } \\
\text { developing country, working } \\
\text { population, and work-related } \\
\text { heat strain }\end{array}$ & $\begin{array}{l}\text { Evaluation of consequence of climatic } \\
\text { variation on vulnerable groups of } \\
\text { people and workers in developing } \\
\text { countries }\end{array}$ & $\begin{array}{l}\text { Heat stress intensifies in workers due to hard physical } \\
\text { work, urban heat island effect, person to person } \\
\text { variation and suggests prevention measure to mitigate } \\
\text { heat stress }\end{array}$ \\
\hline 41 & $\begin{array}{l}\text { Akinnagbe } e t \\
\text { al., (2014) }\end{array}$ & $\begin{array}{l}\text { Reviews of adaptation strategies in the } \\
\text { sector of agriculture against the effect of } \\
\text { climate change }\end{array}$ & $\begin{array}{l}\text { Agricultural } \\
\text { sector }\end{array}$ & $\begin{array}{l}\text { Climate change, effect, risks, } \\
\text { agricultural sector, farmers and } \\
\text { adaptation strategies }\end{array}$ & $\begin{array}{l}\text { Climate change effect on the } \\
\text { agricultural sector and adaptation } \\
\text { strategies }\end{array}$ & $\begin{array}{l}\text { Highlight common agricultural adaptation strategies } \\
\text { and disgusted steps to strengthening human capital }\end{array}$ \\
\hline
\end{tabular}




\begin{tabular}{|c|c|c|c|c|c|c|}
\hline \multicolumn{7}{|c|}{ Continuation of Table 1} \\
\hline $\begin{array}{l}\text { Sl. } \\
\text { No. }\end{array}$ & $\begin{array}{l}\text { Author and } \\
\quad \text { Year }\end{array}$ & ObjectiveStudy & $\begin{array}{l}\text { Study } \\
\text { Inhabitants }\end{array}$ & Learning Theme & Study Involvement & Outcome Data and Study Measure \\
\hline 42 & $\begin{array}{l}\text { Gobin et al., } \\
\text { (2014) }\end{array}$ & $\begin{array}{l}\text { Evaluation and management of weather- } \\
\text { related hazards in agriculture. }\end{array}$ & Farmers & $\begin{array}{l}\text { Weather, hazards, agriculture, } \\
\text { risk, farm income, farm } \\
\text { management, risk, and } \\
\text { policymakers }\end{array}$ & $\begin{array}{l}\text { Influences weather-related hazards in } \\
\text { agriculture }\end{array}$ & $\begin{array}{l}\text { Analysis of weather-related hazards helpful for farm } \\
\text { management and policymakers }\end{array}$ \\
\hline 43 & $\begin{array}{l}\text { Ford et al., } \\
(2011)\end{array}$ & $\begin{array}{l}\text { Climate change adaptation review related } \\
\text { to the developing country }\end{array}$ & $\begin{array}{l}\text { Ordinary people } \\
\text { of developing } \\
\text { country }\end{array}$ & $\begin{array}{l}\text { Literature review, developing } \\
\text { nation, climate change impact, } \\
\text { climate change adaptation }\end{array}$ & $\begin{array}{l}\text { Identification and characterization of } \\
\text { climate change adaptation }\end{array}$ & $\begin{array}{l}\text { Highlight adaptation strategies and monitoring } \\
\text { improvement in a developing country }\end{array}$ \\
\hline 44 & $\begin{array}{l}\text { Heidari } \text { et al., } \\
\text { (2015) }\end{array}$ & $\begin{array}{l}\text { Assessment of heat stress of farmers with } \\
\text { the help of WBGT index }\end{array}$ & Farmers & $\begin{array}{l}\text { Farmer, heat stress, } \\
\text { environmental and biological } \\
\text { monitoring WBGT index and } \\
\text { correlation coefficient }\end{array}$ & $\begin{array}{l}\text { Heat stress measurement by } \\
\text { environmental and biological } \\
\text { monitoring system }\end{array}$ & $\begin{array}{l}\text { Measure hot and humid environment using the WBGT } \\
\text { index, and it can be associated with an overestimation } \\
\text { and encountered our judgment about the environmental } \\
\text { condition with a significant error }\end{array}$ \\
\hline 45 & $\begin{array}{l}\text { Park et al., } \\
(2017)\end{array}$ & $\begin{array}{l}\text { Assessment of the effect of heat on heat } \\
\text { illness of outdoor workers and evaluate the } \\
\text { impact of personal factor to reduce heat } \\
\text { stress }\end{array}$ & Outdoor worker & $\begin{array}{l}\text { Extreme heat, heat stress, heat } \\
\text { illness, WBGT, environmental } \\
\text { factors, personal factors, and } \\
\text { acclimation }\end{array}$ & $\begin{array}{l}\text { Influences of environmental and } \\
\text { personal factors on heat illness of } \\
\text { outdoor workers }\end{array}$ & $\begin{array}{l}\text { Individual risk factors such as environmental factors as } \\
\text { well as heat acclimation and high metabolic rate } \\
\text { throughout work are the chief causes of heart associated } \\
\text { illnesses. }\end{array}$ \\
\hline 46 & $\begin{array}{l}\text { McQueen } e t \\
\text { al., (2012) }\end{array}$ & $\begin{array}{l}\text { Assessment of heat stress of migrant } \\
\text { farmworkers }\end{array}$ & Farmworker & $\begin{array}{l}\text { Heat stress, environmental } \\
\text { body temperature, heart rates, } \\
\text { bodyweight loss, adaptation, } \\
\text { acclimation, and hydration }\end{array}$ & $\begin{array}{l}\text { Evaluation of body warmness } \\
\text { pressure parameters and adaptation } \\
\text { strategies }\end{array}$ & $\begin{array}{l}\text { Propose the necessity for farmworker safety training } \\
\text { regarding hydration and acclimation }\end{array}$ \\
\hline 47 & $\begin{array}{l}\text { Nichols et al., } \\
\text { (2009) }\end{array}$ & $\begin{array}{l}\text { A systematic evaluation of the } \\
\text { consequence of climatic variation on } \\
\text { health and sustainable adaptation } \\
\text { strategies }\end{array}$ & $\begin{array}{l}\text { Common } \\
\text { population }\end{array}$ & $\begin{array}{l}\text { A systematic review, Climate } \\
\text { change, impact, health, and } \\
\text { protection approaches }\end{array}$ & $\begin{array}{l}\text { A consequence of climatic variation } \\
\text { on public health and its mitigation } \\
\text { strategies }\end{array}$ & $\begin{array}{l}\text { Report about climate change impact on health and } \\
\text { highlight action taken to mitigate the impact }\end{array}$ \\
\hline 48 & $\begin{array}{l}\text { Bouzid et al., } \\
\text { (2013) }\end{array}$ & $\begin{array}{l}\text { Evaluation of the usefulness of public } \\
\text { health involvements to reduce a load of } \\
\text { high significance climate-sensitive } \\
\text { illnesses. }\end{array}$ & $\begin{array}{l}\text { Common } \\
\text { population }\end{array}$ & $\begin{array}{l}\text { Climate change, public health, } \\
\text { warmer world, climate- } \\
\text { sensitive illnesses, adaptation, } \\
\text { and future research }\end{array}$ & $\begin{array}{l}\text { Review of climate-sensitive diseases } \\
\text { and usefulness of public health } \\
\text { involvements to reduce the illness }\end{array}$ & $\begin{array}{l}\text { Determine the effectiveness of public health } \\
\text { involvements to reduce climate-sensitive illnesses and } \\
\text { suggest future research }\end{array}$ \\
\hline 49 & $\begin{array}{l}\text { Gao et al., } \\
(2017)\end{array}$ & $\begin{array}{l}\text { A consequence of job-related heat anxiety } \\
\text { on workforces due to climate change and } \\
\text { prevention strategies }\end{array}$ & $\begin{array}{l}\text { Common } \\
\text { working } \\
\text { population }\end{array}$ & $\begin{array}{l}\text { Climate change, global } \\
\text { warming, heat risk, } \\
\text { meteorological data, thermal } \\
\text { climate factors, WBGT, and } \\
\text { Prevention strategies }\end{array}$ & $\begin{array}{l}\text { Review of several designated heat- } \\
\text { related guides, analyse their merit and } \\
\text { demerit in relative to climatological } \\
\text { data }\end{array}$ & $\begin{array}{l}\text { Measure body, Discomfort Index, Predicted Heat Strain } \\
\text { index, heat production, WBGT,etc. and suggest } \\
\text { prevention strategies }\end{array}$ \\
\hline
\end{tabular}




\begin{tabular}{|c|c|c|c|c|c|c|}
\hline \multicolumn{7}{|c|}{ Continuation of Table 1} \\
\hline $\begin{array}{l}\text { Sl. } \\
\text { No. }\end{array}$ & $\begin{array}{l}\text { Author and } \\
\quad \text { Year }\end{array}$ & ObjectiveStudy & $\begin{array}{l}\text { Study } \\
\text { Inhabitants }\end{array}$ & Learning Theme & Study Involvement & Outcome Data and Study Measure \\
\hline 50 & $\begin{array}{l}\text { Kjellstrom et } \\
\text { al., (2017) }\end{array}$ & $\begin{array}{l}\text { Evaluation of health risk due to climate } \\
\text { change and prevention policies in the S.E. } \\
\text { of Asia }\end{array}$ & $\begin{array}{l}\text { People of } \\
\text { South-East Asia }\end{array}$ & $\begin{array}{l}\text { Risk of work-related health and } \\
\text { productivity due to climate } \\
\text { change in southeast Asia } \\
\text { regions }\end{array}$ & $\begin{array}{l}\text { Mitigation of greenhouse gas } \\
\text { production and other prevention } \\
\text { strategies }\end{array}$ & $\begin{array}{l}\text { Gives effective adaptation strategies to crop up climate } \\
\text { change effect and highlight national-level reports on } \\
\text { climate change effect }\end{array}$ \\
\hline 51 & $\begin{array}{l}\text { Ahmed et al., } \\
\text { ( 2019) }\end{array}$ & $\begin{array}{l}\text { Effect of climatic variation in the form of } \\
\text { environmental stressors on the livelihood } \\
\text { of people }\end{array}$ & $\begin{array}{l}\text { People of } \\
\text { Bangladesh }\end{array}$ & $\begin{array}{l}\text { Climate change, environmental } \\
\text { stressor, Bangladesh, } \\
\text { livelihood, insufficient } \\
\text { adaptation strategies, and } \\
\text { illegal livelihoods }\end{array}$ & $\begin{array}{l}\text { Loss of livelihoods due to climate } \\
\text { change and its effect }\end{array}$ & $\begin{array}{l}\text { Describe the raising of Illegal livelihoods due to climate } \\
\text { change and steps to stop it }\end{array}$ \\
\hline 52 & $\begin{array}{l}\text { Mathee et al., } \\
\text { (2010) }\end{array}$ & $\begin{array}{l}\text { Evaluation of awareness of outdoor } \\
\text { workers in the hot working environment } \\
\text { and the consequence of job-related heat } \\
\text { on' health and output of workers }\end{array}$ & Outdoor worker & $\begin{array}{l}\text { Climate change, hot working } \\
\text { environment, the health of the } \\
\text { outdoor worker, and work } \\
\text { output }\end{array}$ & $\begin{array}{l}\text { Evaluation of perception ability of } \\
\text { outdoor workers and protective } \\
\text { measure to cope with warm weather }\end{array}$ & $\begin{array}{l}\text { Lower perception ability of outdoor workers in a hot } \\
\text { environment and loss in productivity and suggest proper } \\
\text { crop up measure }\end{array}$ \\
\hline 53 & $\begin{array}{l}\text { Louis et al., } \\
\text { (2008) }\end{array}$ & $\begin{array}{l}\text { Review of global climate change effect on } \\
\text { health and its significant implication }\end{array}$ & $\begin{array}{l}\text { Common } \\
\text { Populations }\end{array}$ & $\begin{array}{l}\text { Climate Change, greenhouse } \\
\text { gas, global health, mitigation } \\
\text { and adaptation }\end{array}$ & $\begin{array}{l}\text { Mitigation and adaptation of climate } \\
\text { change effect on health }\end{array}$ & $\begin{array}{l}\text { Suggest awareness, strengthening,mitigation, and } \\
\text { adaptation policy reduce climate change effect }\end{array}$ \\
\hline 54 & $\begin{array}{l}\text { Sorensen et } \\
\text { al., (2018) }\end{array}$ & $\begin{array}{l}\text { A consequence of climate change on } \\
\text { women health and the need for appropriate } \\
\text { education policy frameworks }\end{array}$ & $\begin{array}{l}\text { Women } \\
\text { populations }\end{array}$ & $\begin{array}{l}\text { Climate change, women health, } \\
\text { reduction, framework, and } \\
\text { adaptation policy }\end{array}$ & $\begin{array}{l}\text { Policies to mitigate gender-associated } \\
\text { partiality in the application of climatic } \\
\text { variation modification plans }\end{array}$ & $\begin{array}{l}\text { Identify Women health and their economic growth } \\
\text { plays an essential role in the policy of climate change } \\
\text { and empowering of women to improve mitigation and } \\
\text { adaptation policy }\end{array}$ \\
\hline 55 & $\begin{array}{l}\text { Lendrum et } \\
\text { al., (2015) }\end{array}$ & $\begin{array}{l}\text { Review of vector-borne diseases due to } \\
\text { climate change and plan associated } \\
\text { creativities of } \mathrm{WHO} \text { and its partner }\end{array}$ & $\begin{array}{l}\text { Common } \\
\text { populations }\end{array}$ & $\begin{array}{l}\text { Vector-borne disease, climate } \\
\text { change, global public health, } \\
\text { WHO and its partner, health, } \\
\text { policy, and research }\end{array}$ & $\begin{array}{l}\text { Adaptation for vector-borne diseases } \\
\text { and suitable initiatives by the WHO } \\
\text { and its partner }\end{array}$ & $\begin{array}{l}\text { Expose a future project, adaptation strategies, and } \\
\text { suitable initiatives about Vector-borne disease by } \\
\text { WHO and its partner }\end{array}$ \\
\hline 56 & $\begin{array}{l}\text { Hanna et al., } \\
\text { (2015) }\end{array}$ & $\begin{array}{l}\text { Evaluate the risk of climatic variation, } \\
\text { rising heat, etc. and assessment of national } \\
\text { work-related health and safety strategy }\end{array}$ & $\begin{array}{l}\text { Common } \\
\text { working } \\
\text { population }\end{array}$ & $\begin{array}{l}\text { Climatic variation, risky heat } \\
\text { events, heat contact, worker } \\
\text { health, and adaptation }\end{array}$ & $\begin{array}{l}\text { Assessment of health risks associated } \\
\text { with heat contact and mitigation } \\
\text { policy }\end{array}$ & $\begin{array}{l}\text { A consequence of thrilling heat on occupational } \\
\text { healthiness, and protection and mitigation guidelines }\end{array}$ \\
\hline 57 & $\begin{array}{l}\text { Schulte } \text { et al., } \\
\text { (2009) }\end{array}$ & $\begin{array}{l}\text { Development of a primary outline for } \\
\text { identifying the influences of climatic } \\
\text { variation on worker fitness and security }\end{array}$ & $\begin{array}{l}\text { Common } \\
\text { population }\end{array}$ & $\begin{array}{l}\text { Global climate change, heat } \\
\text { stress, category of occupational } \\
\text { hazard and health }\end{array}$ & $\begin{array}{l}\text { The framework of work-related heat } \\
\text { hazard due to global climate change }\end{array}$ & $\begin{array}{l}\text { Given information about a different category of climate } \\
\text { change-related hazards }\end{array}$ \\
\hline
\end{tabular}




\begin{tabular}{|c|c|c|c|c|c|c|}
\hline \multicolumn{7}{|c|}{ Continuation of Table 1} \\
\hline $\begin{array}{l}\text { Sl. } \\
\text { No. }\end{array}$ & $\begin{array}{l}\text { Author and } \\
\quad \text { Year }\end{array}$ & Objective Study & $\begin{array}{l}\text { Study } \\
\text { Inhabitants }\end{array}$ & Learning Theme & Study Involvement & Outcome Data and Study Measure \\
\hline 58 & $\begin{array}{l}\text { Nunfam } e t \\
\text { al., ( 2018) }\end{array}$ & $\begin{array}{l}\text { Observation of heat effect due to climatic } \\
\text { alteration, job associated heat anxiety, and } \\
\text { protection policies among mining workers }\end{array}$ & Mining workers & $\begin{array}{l}\text { Climate change awareness and } \\
\text { hazard due to job associated } \\
\text { warmness pressure and } \\
\text { mitigation approaches }\end{array}$ & $\begin{array}{l}\text { Perspectives about the application of } \\
\text { job associated heat anxiety reduction } \\
\text { of the mining workforce }\end{array}$ & $\begin{array}{l}\text { The function of workers education and preparedness to } \\
\text { mitigate work-related heat stress associated with } \\
\text { climate change and suggest alertness and preparation } \\
\text { advisory on heat stress to minimizing occupational heat } \\
\text { among mining workers }\end{array}$ \\
\hline 59 & $\begin{array}{l}\text { Chersich et } \\
\text { al., (2019) }\end{array}$ & $\begin{array}{l}\text { Evaluation of climatic alteration protection } \\
\text { policy, assessment of awareness intensities } \\
\text { and prevention steps for extreme climate } \\
\text { events }\end{array}$ & $\begin{array}{l}\text { Health sector } \\
\text { population of } \\
\text { South Africa }\end{array}$ & $\begin{array}{l}\text { South Africa, thrilling weather, } \\
\text { health, Prevention for climatic } \\
\text { alteration, and fitnessplan }\end{array}$ & $\begin{array}{l}\text { Protection policy and prevention steps } \\
\text { for risky climate events }\end{array}$ & $\begin{array}{l}\text { Develop Climate change mitigation and adaptation } \\
\text { policy, and awareness of extreme heat events,improve } \\
\text { and strengthening health sector profession and } \\
\text { management }\end{array}$ \\
\hline 60 & $\begin{array}{l}\text { Ylipää et al., } \\
\text { ( 2019) }\end{array}$ & $\begin{array}{l}\text { Evaluation of climate change effects and } \\
\text { weaknesses of workers with adaptation } \\
\text { and gender disparity. }\end{array}$ & $\begin{array}{l}\text { Agricultural } \\
\text { worker }\end{array}$ & $\begin{array}{l}\text { Vietnam, climate change, } \\
\text { gender inequality, agricultural } \\
\text { workers, sustainability, and } \\
\text { adaptation }\end{array}$ & $\begin{array}{l}\text { The requirement of policy to } \\
\text { mitigating the influences of climatic } \\
\text { variation and gender inequality }\end{array}$ & $\begin{array}{l}\text { Develop a policy for gender equality,gender-based } \\
\text { climate change adaptation, and supportable } \\
\text { development }\end{array}$ \\
\hline 61 & $\begin{array}{l}\text { Pogačar et al., } \\
\text { (2017) }\end{array}$ & $\begin{array}{l}\text { Understanding of climatic variation, job } \\
\text { associated heat anxiety effect on farmers } \\
\text { and agricultural advisers. }\end{array}$ & $\begin{array}{l}\text { Farmers and } \\
\text { agricultural } \\
\text { advisers. }\end{array}$ & $\begin{array}{l}\text { Climate change, heatwave, heat } \\
\text { stress, agricultural advisers, } \\
\text { farmers, health, heat-related } \\
\text { illness, productivity, and } \\
\text { mitigation }\end{array}$ & $\begin{array}{l}\text { Responses of farmers and agricultural } \\
\text { advisers under occupational heat } \\
\text { stress }\end{array}$ & $\begin{array}{l}\text { Evaluate the negative effect of occupational heat stress } \\
\text { is determined by survey and suggest mitigation } \\
\text { strategies }\end{array}$ \\
\hline 62 & $\begin{array}{l}\text { Swaminathan } \\
\text { et al., (2016) }\end{array}$ & $\begin{array}{l}\text { A consequence of thrilling weather events } \\
\text { for climatic alternation on Indian } \\
\text { agriculture and its adaptation strategies }\end{array}$ & $\begin{array}{l}\text { South } \\
\text { Australian } \\
\text { workers' }\end{array}$ & $\begin{array}{l}\text { Climate change, extreme } \\
\text { weather event, crop yield, } \\
\text { agricultural productivity, } \\
\text { farmers livelihood, and } \\
\text { adaptation strategies }\end{array}$ & $\begin{array}{l}\text { Effect of climate change on crop yield } \\
\text { and farmers livelihood }\end{array}$ & $\begin{array}{l}\text { How extreme weather event affect crop yield and } \\
\text { farmers livelihood and suggest field-level operational } \\
\text { strategies and simple few adaptation strategies reduce } \\
\text { the effect }\end{array}$ \\
\hline 63 & $\begin{array}{l}\text { Day et al., } \\
\text { (2018) }\end{array}$ & $\begin{array}{l}\text { Evaluation of the influence of climacteric } \\
\text { variation on workers productivity and } \\
\text { maintenance of workers productivity } \\
\text { under climate change with proper } \\
\text { adaptation }\end{array}$ & $\begin{array}{l}\text { Common } \\
\text { workers }\end{array}$ & $\begin{array}{l}\text { climacteric variation, heat } \\
\text { anxiety, labor productivity, and } \\
\text { mitigation policies }\end{array}$ & $\begin{array}{l}\text { Influence of heat on workers'output } \\
\text { and required adequate protection } \\
\text { strategies }\end{array}$ & $\begin{array}{l}\text { Productivity loss of workers causes crucial economic } \\
\text { impacts on nations and suggest effective adaptation }\end{array}$ \\
\hline 64 & $\begin{array}{l}\text { Balanagarajan } \\
\text { et al., (2018) }\end{array}$ & $\begin{array}{l}\text { Effect of negative consequence climacteric } \\
\text { variation on employee's health and output }\end{array}$ & $\begin{array}{l}\text { Employee' of } \\
\text { different sector }\end{array}$ & $\begin{array}{l}\text { Human health, climate change, } \\
\text { global warming, employee } \\
\text { productivity, and awareness }\end{array}$ & $\begin{array}{l}\text { climacteric variation effect on } \\
\text { employees healthiness and output }\end{array}$ & $\begin{array}{l}\text { Climate change causes a reduction in employees' } \\
\text { productivity and how employees' knowledge and } \\
\text { awareness and knowledge about the climatic changes } \\
\text { help them adapt themselves and become more } \\
\text { productive. }\end{array}$ \\
\hline 65 & $\begin{array}{l}\text { Moda and } \\
\text { Alshahrani } \\
\text { (2018) }\end{array}$ & $\begin{array}{l}\text { Assessment of the effect of elevated } \\
\text { temperature and extreme heat on the safety } \\
\text { and comfort of outdoor workers }\end{array}$ & $\begin{array}{l}\text { Outdoor worker } \\
\text { of Jizan }\end{array}$ & $\begin{array}{l}\text { Elevated temperature, extreme } \\
\text { heat, outdoor workers, heat } \\
\text { exposure, adaptation strategy }\end{array}$ & $\begin{array}{l}\text { Evaluation of awareness of outdoor } \\
\text { workers working in hot weather and } \\
\text { adaptation strategies for their health }\end{array}$ & $\begin{array}{l}\text { Extreme heat increase occupational injuries and heat } \\
\text { illness and reduce the working capacity of outdoor } \\
\text { workers }\end{array}$ \\
\hline
\end{tabular}


Int.J.Curr.Microbiol.App.Sci (2021) 10(02): 2947-2975

\begin{tabular}{|c|c|c|c|c|c|c|}
\hline \multicolumn{7}{|c|}{ Continuation of Table 1} \\
\hline $\begin{array}{l}\text { Sl. } \\
\text { No. }\end{array}$ & $\begin{array}{l}\text { Author and } \\
\text { Year }\end{array}$ & Objective Study & $\begin{array}{l}\text { Study } \\
\text { Inhabitants }\end{array}$ & Learning Theme & Study Involvement & Outcome Data and Study Measure \\
\hline 66 & $\begin{array}{l}\text { Varghese } \text { et } \\
\text { al., (2018) }\end{array}$ & $\begin{array}{l}\text { Evaluation of the effect of ambient } \\
\text { temperature on the hazard of occupational } \\
\text { injury and illness }\end{array}$ & $\begin{array}{l}\text { Common } \\
\text { worker }\end{array}$ & $\begin{array}{l}\text { Ambient temperature, heat } \\
\text { exposure, occupational injury } \\
\text { and illness, health and safety }\end{array}$ & $\begin{array}{l}\text { Effect of heat on workers due to heat } \\
\text { exposure and causes of occupational } \\
\text { injuries }\end{array}$ & $\begin{array}{l}\text { The requirement of increasing Consciousness of work- } \\
\text { related injury and the financial benefits associated with } \\
\text { the reduction of } v \text { prevention injury and productivity } \\
\text { loss and examine the worker's risk of work-related heat } \\
\text { exposure and specific injuries }\end{array}$ \\
\hline 67 & $\begin{array}{l}\text { Shenga et al., } \\
\text { (2018) }\end{array}$ & $\begin{array}{l}\text { Evaluation of the association of extreme } \\
\text { hotness and Job-related injury }\end{array}$ & $\begin{array}{l}\text { Guangzhou } \\
\text { working } \\
\text { population }\end{array}$ & $\begin{array}{l}\text { Climate change, hot weather, } \\
\text { extreme heat exposure, work } \\
\text { injury, and occupational health }\end{array}$ & $\begin{array}{l}\text { Evaluate injury associate with work } \\
\text { due to hot weather exposure }\end{array}$ & $\begin{array}{l}\text { Define the consequence of Climatic variation effecton } \\
\text { employees and adaptation policy }\end{array}$ \\
\hline 68 & $\begin{array}{l}\text { Cora Roelofs } \\
(2019)\end{array}$ & $\begin{array}{l}\text { Climatic variation hazard on workers' } \\
\text { health and safety }\end{array}$ & $\begin{array}{l}\text { common } \\
\text { workers }\end{array}$ & $\begin{array}{l}\text { Climatic variation, hot } \\
\text { environment, hot condition, } \\
\text { heat risk, heat illness, and risk } \\
\text { reduction measure }\end{array}$ & $\begin{array}{l}\text { Climatic variation influences labors } \\
\text { and risk reduction strategies }\end{array}$ & $\begin{array}{l}\text { Highlights different Climate change influences on } \\
\text { workers and suggest risk-reduction approaches }\end{array}$ \\
\hline 69 & $\begin{array}{l}\text { Nicholas H. } \\
\text { Ogden (2017) }\end{array}$ & $\begin{array}{l}\text { Review of the probable impression of } \\
\text { Climatic variation on vector-borne } \\
\text { illnesses }\end{array}$ & $\begin{array}{l}\text { Common } \\
\text { population }\end{array}$ & $\begin{array}{l}\text { Climate alteration, the } \\
\text { influence of Climatic variation, } \\
\text { public health, vector-borne } \\
\text { disease }\end{array}$ & $\begin{array}{l}\text { Risk of vector-borne diseases on } \\
\text { public health due to climate change }\end{array}$ & $\begin{array}{l}\text { Highlight the evidence of vector-borne conditions on } \\
\text { public health due to climate change }\end{array}$ \\
\hline
\end{tabular}


Fig.1

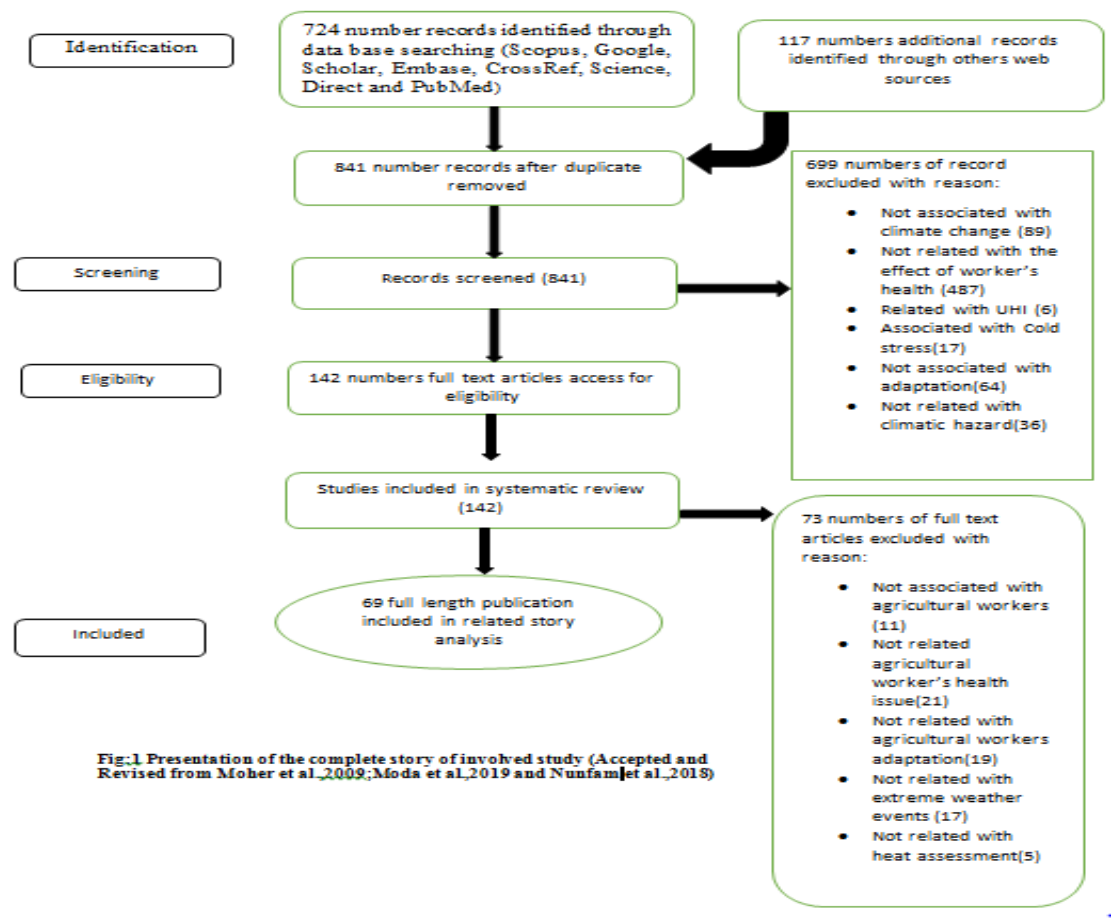

Fig.2 Representation of direct heat effect on agricultural workers with relative factors (Idea taken and improved from Varghese et al., 2018; Raouf, 2012; Makinen and Hassi, 2009; Kjellstrom et al., 2016)

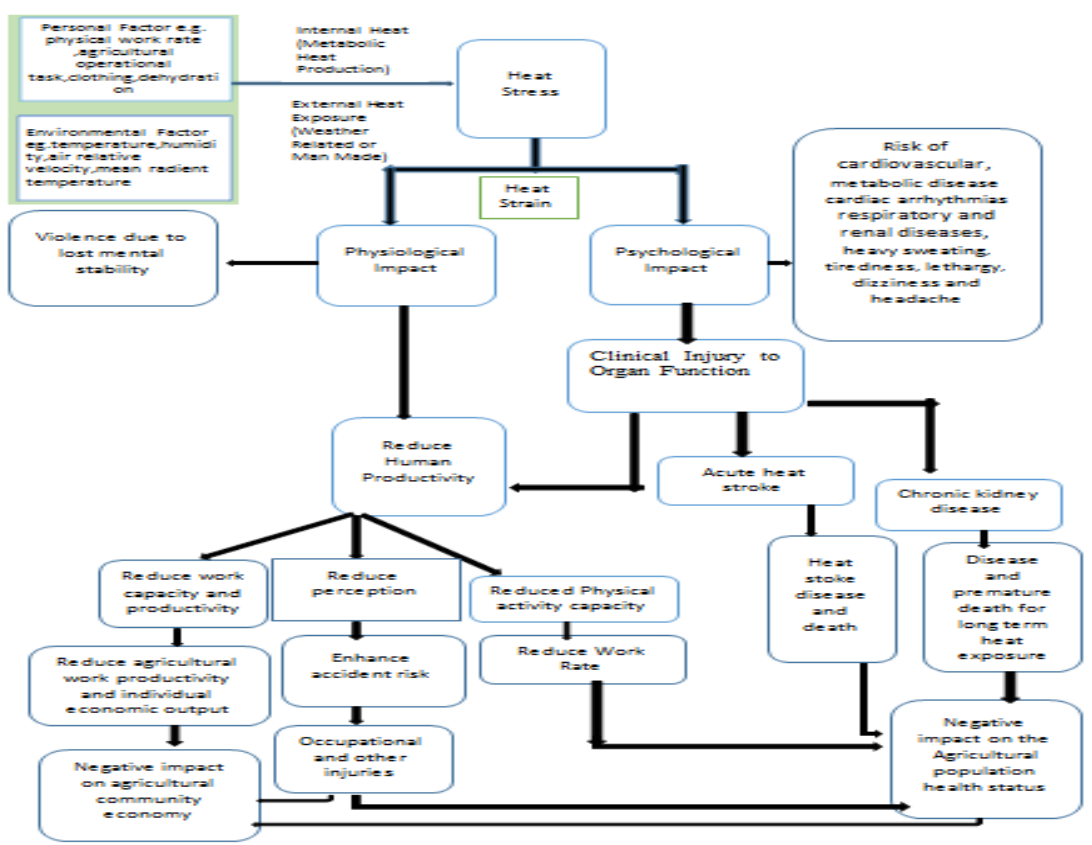


Air pollution considerably affects workers' health; about seven million per year mortality occurs due to air pollution (Orru et al., 2017). Wildfires and droughts both play essential roles in air pollution. The continuously increasing pollen production and lengthier pollen periods are producing more allergic disorders among agricultural workers. Outdoor agricultural workers are commonly impacted by air pollution as they work in an open environment (Levy and Roelofs, 2019). The productivity of outdoor workers is directly related to air quality. With improving air quality, the productivity of workers also improves and vice versa. Earlier research shows that generally increases ground-level ozone and FPM (PM2.5) led to significant decreases in outdoor agricultural workers (Matthew Neidell, 2017). Besides, Arslan and Aybek, (2012) stated that in dry conditions or drought conditions, agricultural practices such as plowing, horrowing, transplanting, harvesting, threshing, etc., producing a significant amount of dust. This particular matter in the form of dust directly affects the respiratory system of outdoor farmworkers.

Kirkhorn et al., (2000) found that considerable numbers of agricultural workers are associated with clinical symptoms with long-term exposure to organic dust due to working in draught and dry weather conditions. Due to dry and hot weather in the agriculture sector, organic dust and toxic gases make it the riskiest occupation. Further, farmworkers are much more influence by air contamination than other workers (Schulte et al., 2016). The common diseases of farmers due to enduring expose to dusty condition are organic dust toxic syndrome, allergic disorders, central nervous system dysfunctions, asthma, lung cancer, mucous membrane inflammation syndrome, cardiovascular illness, hypersensitivity pneumonitis, cutaneous diseases, chronic bronchitis, etc. (Manisalidis et al., 2020; Kirkhorn et al., 2000; Schulte et al., 2016;
Kiefer et al., 2016; William J. Fisk., 2014).

Fang et al., 2013 reported that around $85 \%$ and $95 \%$ of mortalities for air pollution due to $\mathrm{O}_{3}$ and $\mathrm{PM} 2.5$, respectively. They also found that cumulative $\mathrm{CH}_{4}$ concentrations and climate change are also responsible for around $15 \%$ and $5 \%$, respectively, of premature mortality. Apart from air pollution causes a direct effect on crop yield, which influences the farmer's economy (S. Ahmed, 2015; Burney et al., 2013).

\section{Vector-borne diseases and additional biological hazards}

Apart from the straight impact produced by thrilling heat contact, other indirect health hazards related to climatic variation among agricultural workers are contacts to harmful chemicals and other vector-borne diseases (Moda et al., 2019). Due to the variety of occupations, we found limited literature on specific biological hazards and an agricultural worker's vector bone disease. Climate change plays a considerable role in spreading vector bone diseases .Climate change effects such as temperature, flood, etc., help grow vectors by providing suitable environmental support for a vector growth cycle, waterborne and foodborne pathogens development.

Żukiewicz-Sobczak et al., (2013) explore in their study that for limited health care, unhealthy working conditions, and lack of proper health education, agricultural workers' health status is generally inferior to other workers. Due to the work characteristic of agricultural workers, they commonly come across natural hazards and Vector-borne diseases from different microorganisms and biological agent (bacteria, fungi, viruses, parasites, poisonous plants, venomous insects and reptiles, non-vector-borne pathogens, and toxic plants) (Żukiewicz-Sobczak et al., 2013; Rim et al., 2013). 
Further, climate change causes various disease vectors such as mosquitoes, ticks, rodents, fleas, etc., which are spread the vector bone disease such as dengue, West Nile, malaria, chikungunya, Lyme illness, diarrheal, allergic disease. (Levy and Roelofs, 2019; Moore et al., 2017;Kiefer et al., 2016; Schulte et al., 2016; Nicholas H. Ogden, 2017;Lendrum et al., 2015). More pesticides are required to control these disease vectors, which increase the chances of pesticide contract to agricultural workers (Boxall et al., 2010; Gatto, Cabella, and Gherardi, 2016; Levy and Roelofs, 2019). Apart from this, aquatic diarrheal illness is also related to climate inconsistency, which may influence the workers in occupations such as agriculture and fishing (Schulte et al., 2016; Nichols et al., 2009). Ostfeld et al., (2015) and Schulte et al., (2016) reported that workers working in an open environment have up to a five times advanced threat for Lyme illness than typical indoor employees.

Some of the allergic diseases spared by airborne allergens such as plant pollen, mold, fungal spores, etc., are climate-sensitive (Schulte et al., 2016; Kiefer et al., 2016). Besides all the vectorborne diseases, temperatures, and $\mathrm{CO}_{2}$ also raise the growth of toxic ivy and other poisonous plants, which may influence farmers' health (Kiefer et al., 2016).

\section{Ultraviolet radiation}

Climate change plays a vital role indirectly in ultraviolet radiation by influencing the atmospheric percentage of ozone, aerosols, clouds, and ultraviolet-absorbing gases (Bais et al., 2015; Schulte et al., 2016). U.V. radiations are easily absorbed in the human skin and cause adverse health impacts, especially in the eye and skin. Previous research is exposed that compared to longer U.V. waves, the shorter wavelength of U.V. radiation is more destructive for the human body. Workers who work in outdoor environmental conditions are positively affected by U.V. radiation. Outdoor workers who are mostly working under sun ray without any proper protection are commonly affected by skin aging, skin cancer, declining immunity, and eye damage problems (photokeratitis and cataracts) (WHO, 2003; Jaggernath et al., 2013; Schulte et al., 2016; Kiefer et al., 2014). Apart from affecting the health of farmers, the U.V. radiation also causes a reduction in crop production, variation in weed-crop synergies quality of crops, and fertility, which directly influences the life of agricultural workers (Open Weather, 2018).

\section{Psychological stress}

Climate change impacts workers' physical health and plays a considerable effect on workers' mental health (Cianconi et al., 2020; Moda et al., 2019; Padhy et al., 2015). Earlier research exposes that mental health disturbance is more common in farmworkers and farmers than other workers of different sectors (Yazd et al., 2019). By systematic review of the literature, we have identified that financial difficulty, drought, changing pattern of rain, exposure to pesticide, etc. are considerably affecting the mental health of farmers (Yazd et al., 201; Padhy et al., 2015Rasanen et al., 2016).

\section{Approaches for assessing the effect of climate change on agricultural workers}

We have already highlighted the direct and indirect influences of climatic variation on agricultural workers' health. Because of the lack of appropriate, relevant data, it has been difficult to assess how vulnerable and at-risk are due to climatic variation on agricultural workers. We have only reviewed the earlier approaches to evaluate heat stress in 
agricultural workers to address these issues. We have already exposed the heat stress effect on farmworkers. More initial research highlighted that skin temperature, blood pressure, core body temperature(CBT), body mass loss, and heart rate are the most consistent process for assessing the hazard of heat stress (Juliana Bunim, 2013). Still, such measurements may restrict work movements, are offensive, and should only be achieved by people with medical training (StaalWästerlund, 2018). Gao et al., (2017), Zamanian et al., 2017 Singh et al., 2018 suggested that the evaluation of climatological facts such as air temperature mean temperature of the surrounding area, air velocity, humidity, and heat radiation are also essential to measure occupational heat stress OSHA, (2017).Heat stress and heat strain computing by Discomfort Index, Universal Thermal Climate Index, Predicted Heat, Wet Bulb Globe Temperature(WBGT), and Strained index (Gao et al., (2017).Out of the mentioned method, WBGT is the most common, predominant index, and popular way to access workers' heat stress(G. M Budd;2008) Al-Bouwarthan et al., 2019. WBGT and Humidex are maximum precise approaches to display a healthier association with physiological parameters under heat stress working conditions of agricultural workers OSHA, (2017), Gao et al., (2017) Kjellstrom et al., 2009. Heat stress measure using the WBGT index according to ISO 7243, heat strain was evaluated using by determining the different physiological responses, including mean skin temperatures, oral and aural, rendering to ISO 9886 Heidari et al., (2015). Ken Parsons, 2006; Kirti Kesarwani (2017). Early studies showed that WBGT index values had to range from 24 to $32.6{ }^{\circ} \mathrm{C}$ in the hot season irrespective of metabolic rate, work rest, and clothing insulation (Heidari et al., 2015; Kirti Kesarwani, 2017;). Kashyap et al., (2017) found that the mean skin temperature and oral temperature of workers increase with the increase in WBGT With the increment of WBGT from 28 to $30^{\circ} \mathrm{C}$. Physiological parameters like resting and working heart rate increase with an increase in WBGT. The physical discomfort parameter overall discomfort rate (ODR) increases with an increase from 4.9to 6.7 during the same working condition in WBGT due to heat stress.

\section{Interventions and strategies for preventing the effect of climate change on agricultural workers}

After analyzing the previous research priorities, we expose some prevention and adaptation strategies that may help protect agriculture workers from the adverse consequence of climatic variation. The control of climatic change measures is usually beyond human capability, but following some precaution, Prevention, and adaptation strategies we exposed can mitigate the effect of climate change on human health. Nowadays, job associated heat contact is a burning contest for workers' safety and health. An international agency such as WHO, ILO, WMO, ISO, etc., has been given many climate change adaptation strategies on typical workers' occupational health (Nilsson et al., 2010). As we have already highlighted that in the case of agricultural workers, occupational heat hazard is a principal challenge for their health and safety, so we are only focused on those prevention and adaptation strategies that are suitable for agricultural workers to mitigate the heat stress.

Further, before selecting the strategies, we have kept in mind that the prevention and adaptation measure should be capable enough to protect outdoor workers from minimizing the social difficulties, economy, and productivity losses (ILO, 2019; UNDP, 2016; 
Moda et al., 2019). Due to increasing the rates of mortality and mobility by extreme weather hazards, there are healthy needs for rational assessments of vulnerability and threat to improve the knowledge about occupational risk for risk management, agricultural management practices, adaptation and mitigation of climate change effect Schulte et al., (2016) Sherwood et al., 2010 Thomas et al., 2014, Akinnagbe et al., 2014 Ford et al., 2011 Louis et al., 2008, Chersich et al., 2019. Increasing the use of renewable energy or substitute for fossil fuel also plays an essential role in mitigating the climate change effect.

Apart from (Xiang et al., 2016) expose five aspects of workers' awareness about the risk in their study, these are the modification of work habits, anxieties about heat exposure, policy and guideline support, degree of satisfaction preventive and measures arrogances towards more training. Deressa et al., 2010 mentioned that the most important factors that influence the adaptation strategies of climate change for farmworkers are family size, literacy of the head of the family, gender of the family head, livestock status, and manner of crop production (whether mechanized or not, etc.

Recommended some adaptation strategies for agricultural workers such as the provision of proper shade for resting or other suitable means to recover from heat stress, availability of drinking water at the workplace, use of cooling mechanisms, shifting of work, conducting training and awareness program associated with heat safety (Jackson and Rosenberg, 2010, Nunfam et al., 2018 and Crowe et al., 2009 Lam et al., 2013). They also state that assessment of risk due to extreme occupational heat by agricultural workers and proper management practices are also important measures to mitigate the climate change negative impact in the farming sector.
In conclusion the adverse influences of climatic variation on job associated safety and health has been extensively studied on the general population rather than agricultural workers. Even though limited familiar suggestion exists on climate change effect of work-related health and safety among outdoor agricultural workers of a developing country, our systematic review's outcome helps in the assessment of climate change effect on agricultural workers approaches for assessing the impact of heat stress and finding of adaptation strategies. After a systematic review, we are found that climate changerelated hazards like extreme weather events, extreme heat, air pollution, high level of $\mathrm{O}_{3}$,psychological Stress, ultraviolet exposure, vector-borne diseases, and other biological hazards are affecting tremendously outdoor agricultural workers' health and productivity. Besides, due to occupational heat exposure in a tropical developing country, agricultural workers quickly come across heat stress, heat illness, and occupational injury, which may eventually cause death. Further global warming due to climate change plays a vital role in increasing pathogens, insect pests, and weeds, leading to an increase in the use of pesticides, herbicides, and other chemicals that may cause serious health effects on agricultural workers. At last, we highlight some adaptation strategies from our finding of outdoor farmworkers such as the provision of proper shade for resting or other suitable means to recover from heat stress, availability of drinking water at the workplace, use of supportable protective equipment's to mitigate the negative effect of climate change on health, conducting training and awareness program associated with heat safety. Apart from the above consideration, there is an essential need for scientific research work to assess the impact of climate change on agricultural workers' working capacity in a tropical developing country and develop some mechanism to cope with the changing 
climatic conditions for sustaining the livelihood of agricultural workers.

\section{References}

Acharya, P., Boggess, B., and Zhang, K. (2018). Assessing heat stress and health among construction workers in a changing climate: a review. International journal of environmental research and public health, 15(2), 247.

Adam-Poupart, A., Labrèche, F., Smargiassi, A., Duguay, P., Busque, M. A., Gagné, C., Rintamäki, H., Kjellstrom, T., \&Zayed, J. (2013). Climate change and Occupational Health and Safety in a temperate climate: potential impacts and research priorities in Quebec, Canada. Industrial Health, 51(1), 68-78.

Adam-Poupart, A. (2013). Impacts of climate change on occupational health and safety. Institut de Recherché, Quebec. http://www. irsst. qc. $\mathrm{ca} /$ media/documents/PubIRSST.

Adrian, S. C., Sergiu, C., Maria, M., Anca, S. C., and Monica, M. (2008). Models for the indices of thermal comfort. Journal of Medicine and Life, 1(2), 148.

Ahmed, I., Ayeb-Karlsson, S., van der Geest, K., Huq, S., and Jordan, J. C. (2019). Climate change, environmental Stress, and loss of livelihoods can push people towards illegal activities: a case study from coastal Bangladesh. Climate and Development, 11(10), 907-917.

Ahmed, S. (2015). Air pollution and its impact on agricultural crops in developing countries-a review. J. Anim. Plant Sci, 25, 297-302.

Akinnagbe, O. M., and Irohibe, I. J. (2014). Agricultural adaptation strategies to climate change impacts in Africa: a review. Bangladesh Journal of Agricultural Research, 39(3), 407-418.

Applebaum, K. M., Graham, J., Gray, G. M., LaPuma, P., McCormick, S. A., Northcross, A. and Perry, M. J. (2016). An Overview of Occupational Risks
From Climate Change. Current environmental health reports, 3(1), 13-22.

Arslan, S., and Aybek, A. (2012). Particulate matter exposure in agriculture. Air Pollution. A Comprehensive Perspective, 3.SS

Al-Bouwarthan, M., Quinn, M. M., Kriebel, D. and Wegman, D. H. (2019). Assessment of heat stress exposure among construction workers in the hot desert climate of Saudi Arabia. Annals of work exposures and health, 63(5), 505-520.

Bais, A. F., McKenzie, R. L., Bernhard, G., Aucamp, P. J., Ilyas, M., Madronich, S., and Tourpali, K. (2015). Ozone depletion and climate change: impacts on U.V. radiation. Photochemical and Photobiological Sciences, 14(1), 19-52.

Balanagarajan, K., and Gajapathy, V. (2018). Climate change and its impact on employee productivity. International Journal of Applied Engineering Research, 13(1), 27-29.

Balbus, J. M., Boxall, A. B., Fenske, R. A., McKone, T. E., and Zeise, L. (2013). Implications of global climate change for the assessment and management of human health risks of chemicals in the natural environment. Environmental toxicology and chemistry, 32(1), 62-78.

Barange, M., Bahri, T., Beveridge, M.C.M., Cochrane, K.L., Funge-Smith, S. and Poulain, F., eds. (2018). Impacts of climate change on fisheries and aquaculture: synthesis of current knowledge, adaptation, and mitigation options. FAO Fisheries and Aquaculture Technical Paper No. 627. Rome, FAO. $628 \mathrm{p}$

Barnett, J., and Webber, M. (2009, March). Accommodating Migration to Promote Adaptation to Climate Change. Retrieved August 25, 2020, from https://www.preventionweb.net

Bilbeisi, K. M., and Kesse, M. (2017). Tesla: A successful entrepreneurship strategy. Morrow, GA: Clayton State University. Pp 1-10. https://www.westga.edu/ bquest/2017/tesla2017.pdf 
Bouzid, M., Hooper, L., and Hunter, P. R. (2013). The effectiveness of public health interventions to reduce the health impact of climate change: a systematic review of systematic reviews. PloS one, 8(4), e62041.

Boxall, A. B., Hardy, A., Beulke, S., Boucard, T., Burgin, L., Falloon, P. D., and Levy, L. S. (2009). Impacts of climate change on indirect human exposure to pathogens and chemicals from agriculture. Environmental health perspectives, 117(4), 508-514.

Brooks, S. K., Dunn, R., Sage, C. A. M., Amlôt, R., Greenberg, N., and Rubin, G. J. (2015). Risk and resilience factors affecting the psychological wellbeing of individuals deployed in humanitarian relief roles after a disaster. Journal of Mental Health, 24(6), 385-413. DOI:10.3109/09638237.2015.1057334

Bugajska, J., Makowiec-Dąbrowska, T., Jegier, A., and Marszałek, A. (2005). Physical work capacity (VO2 max) and work ability (WAI) of active employees (men and women) in Poland. International Congress Series, 1280, 156-160. doi:10.1016/j.ics.2005.03.001

Bunim, J. (2013). Higher Calorie Diets Shorten Hospital Stays for Teens with Anorexia. Retrieved September 13, 2020, from https://www. ucsfbenioffchildrens.org/

Burney, J., and Ramanathan, V. (2014). Recent climate and air pollution impacts on Indian agriculture. Proceedings of the National Academy of Sciences, 111(46), 16319-16324.

Burney, J., and Ramanathan, V. (2014). Recent climate and air pollution impacts on Indian agriculture. Proceedings of the National Academy of Sciences, 111(46), 16319-16324.

Campbell-Lendrum, D., Manga, L., Bagayoko, M., and Sommerfeld, J. (2015). Climate change and vector-borne diseases: what are the implications for public health research and policy? Philosophical Transactions of the Royal Society B: Biological Sciences, 370(1665),
20130552.

Chersich, M. F., and Wright, C. Y. (2019). Climate change adaptation in South Africa: a case study on the role of the health sector. Globalization and health, 15(1), 22.

Cianconi, P., Betrò, S., and Janiri, L. (2020). The impact of climate change on mental health: a systematic descriptive review frontiers in psychiatry, 11.

Cogato, A., Meggio, F., De Antoni Migliorati, M., and Marinello, F. (2019). Extreme weather events in agriculture: A systematic review. Sustainability, 11(9), 2547.

Conforti, P., Ahmed, S., and Markova, G. (2018). Impact of disasters and crises on agriculture and food security, 2017.

Cooper, K. E. (1996). Basic thermoregulation. In Comprehensive Human Physiology (pp. 2199-2206). Springer, Berlin, Heidelberg.

Crowe, J., van Wendel de Joode, B., and Wesseling, C. (2009). A pilot field evaluation on heat stress in sugarcane workers in Costa Rica: What to do next? Global Health Action, 2(1), 2062.

Daghagh Yazd, S., Wheeler, S. A., and Zuo, A. (2019). Key risk factors affecting farmers' mental health: A systematic reviewinternational journal of environmental research and public health, 16(23), 4849.

Day, E., Fankhauser, S., Kingsmill, N., Costa, H., and Mavrogianni, A. (2019). Upholding labour productivity under climate change: an assessment of adaptation options. Climate policy, 19(3), 367-385.

Deressa, T. T., Hassan, R. M., and Ringler, C. (2011). Perception of and adaptation to climate change by farmers in the Nile basin of Ethiopia. The Journal of Agricultural Science, 149(1), 2331.DOI:10.1080/14693062.2018.1517640

De, U. S., Dube, R. K., and Rao, G. P. (2005). Extreme weather events over India in the last 100 years. J. Ind. Geophys. Union, 9(3), 173-187.

Detz, J. (2020, July 03). Adverse Human Health 
Outcomes Linked to Climate Change. Retrieved August 22, 2020, fromhttps://webcache.googleusercontent.c om/

Ebi, K. L., and McGregor, G. (2008). Climate change, tropospheric ozone, and particulate matter, and health impacts. Environmental health perspectives, 116(11), 1449-1455. (Ebi\& McGregor, 2008).

EPA. (2020, September 01). Ground-level Ozone Basics. Retrieved September 03, 2020, from https://www.epa.gov/groundlevel-ozone-pollution/ground-levelozone-basics

Fang, Y., Naik, V., Horowitz, L. W., and Mauzerall, D. L. (2013). Air pollution and associated human mortality: the role of air pollutant emissions, climate change, and methane concentration increases from the preindustrial period to the present. Atmospheric Chemistry and Physics, 13(3), 1377-1394.

Fann, N., Brennan, T., Dolwick, P., Gamble, J., Ilacqua, V., Kolb, L., Ziska, L. (2016, April 04). Ch. 3: Air Quality Impacts. Retrieved September 03, 2020, from https://health2016. globalchange.gov/airquality-impacts

Fantozzi, F., and Lamberti, G. (2019). Determination of Thermal Comfort in Indoor Sports Facilities Located in Moderate Environments: An Overview. Atmosphere, 10(12), 769.

FICCI. (2015, March 09). labour in Indian agriculture: a growing challenge. Retrieved August 23, 2020, from http://ficci.in/spdocument/20550/FICCI

Fisk, W. J. (2015). Review of some effects of climate change on indoor environmental quality and health and associated noregrets mitigation measures. Building and Environment, 86, 70-80.

Flocks, J., Vi Thien Mac, V., Runkle, J., TovarAguilar, J. A., Economos, J., and McCauley, L. A. (2013). Female farmworkers' perceptions of heat-related illness and pregnancy health. Journal of ago medicine, 18(4), 350-358.
Flouris, A. D., Dinas, P. C., Ioannou, L. G., Nybo, L., Havenith, G., Kenny, G. P., and Kjellstrom, T. (2018). Workers' health and productivity under occupational heat strain: a systematic review and metaanalysis. The Lancet Planetary Health, 2(12), e521-e531.

Ford, J. D., Berrang-Ford, L., and Paterson, J. (2011). A systematic review of observed climate change adaptation in developed nations. Climatic change, 106(2), 327-336

Gatto, M. P., Cabella, R., and Gherardi, M. (2016). Climate change: The potential impact on occupational exposure to pesticides. Annali dell' IstitutoSuperiore Di. Sanita, 52, 374-385. Find this resource: Gonzalez, G. (2017, November 8). OSHA resumes enforcement in Irmaaffected areas. Business Insurance. Find this resource:

Gobin, A., Tarquis, A.M. and Dalezios, N. (2013). Preface "Weather-related hazards and risks in agriculture." Natural Hazards And Earth System Science, 13(10), 25992603. https://doi.org/10.5194/nhess-132599-2013.

Gubernot, D. M., Anderson, G. B., and Hunting, K. L. (2014). The epidemiology of occupational heat exposure in the United States: a review of the literature and assessment of research needs in a changing climate. International journal of biometeorology, 58(8), 1779-1788.

Hancock, P. A., and Vasmatzidis, I. (2003). Effects of heat stress on cognitive performance: the current state of knowledge. International Journal of Hyperthermia, 19(3), 355-372.Health, 23(2_suppl), 14S-26S.

Halawa, E., and van, Hoof, J. (2012). The adaptive approach to thermal comfort: A critical overview. Energy and Buildings, 51, 101-110. doi:10.1016/j.enbuild.2012.04.011

Handmer, J., Honda, Y., Kundzewicz, Z. W., Arnell, N., Benito, G., Hatfield, J and Takahashi, K. (2012). Changes in impacts of climate extremes: human systems and ecosystems. Managing the risks of 
extreme events and disasters to advance climate change adaptation special report of the intergovernmental panel on climate change (pp. 231-290).Intergovernmental Panel on Climate Change.

Hanna, E. G., Kjellstrom, T., Bennett, C., and Dear, K. (2011). Climate change and rising heat: population health implications for working people in Australia. Asia Pacific Journal of Public

Heidari, H., Golbabaei, F., Shamsipour, A., Rahimi-Forushani, A. B. B. A. S., and Gaeini, A. (2015). Evaluation of heat stress among farmers using Environmental and biological monitoring: a study in the north of Iran. International Journal of Occupational Hygiene, 7(1), 19.

Huang, C., Barnett, A. G., Wang, X., Vaneckova, P., FitzGerald, G., and Tong, S. (2011). Projecting future heat-related mortality under climate change scenarios: a systematic review. Environmental health perspectives, 119(12), 1681-1690.

Hunter, A., and Hewson, J. (2020, June 23). There are ten catastrophic threats facing humans right now, and coronavirus is only one of them. Retrieved August 23, 2020, from https://theconversation.com/there-are-10catastrophic-threats-facing-humans-rightnow-and-coronavirus-is-only-one-ofthem-136854.

ILO.(2019).Working on a warmer planet. The impact of heat stress on labour productivity and decent work. Input Document for the G20 Climate Sustainability Working Group International Labour Office - Geneva. ISBN 978-92-2-132968-8 (web pdf). Retrieved August 23, 2020 fromhttps://www.ilo.org/wcmsp5/groups/ public/.

IPCC. International Panel on Climate Change.Fourth assessment report. Geneva, Switzerland: Intergovernmental Panel on Climate Change; 2007. Report No.: AR4. Available from: http://www.ipcc.ch/publications_and_data /publications_ipcc_fourth

_assessment_report synthesis_report. htm

Jackson, L. L., and Rosenberg, H. R. (2010).

Preventing heat-related illness among agricultural workers. Journal of ago medicine, 15(3), 200-215.

Jaggernath, J., Haslam, D., and Naidoo, K. S. (2013). Climate change: Impact of increased ultraviolet radiation and water changes on eye health. 5(05), 921.

Jenkins, M. (2019, November 07). What is ASHRAE 55? Basics of Thermal Comfort: SimScale Blog. Retrieved September 02, 2020, from https://www.simscale.com/blog/

Kesarwani, K.(2017) Occupational heat stress among farmworkers and intervention to reduce ill effects (Doctoral dissertation, GB Pant University of Agriculture and Technology, Pantnagar-263145 (Uttarakhand))

Kiefer, M., Lincoln, J., Schulte, P., and Jacklitsch, B. (2014, September 22). Climate Change and Occupational Safety and Health. Retrieved August 27, 2020, from https://blogs.cdc.gov/niosh-scienceblog/2014/09/22/climate-change/

Kjellstrom, T., and Crowe, J. (2011). Climate change, workplace heat exposure, and occupational health and productivity in Central America. International Journal of Occupational and Environmental Health, 17(3), 270-281

Kjellstrom, T., Lemke, B., Otto, P. M., Hyatt, O. M., Briggs, D. J., and Freyberg, C. A. (2015). Heat impacts work, human performance, and daily life. Climate Change and Public Health, 73-86.

Kiefer, M., Rodríguez-Guzmán, J., Watson, J., van Wendel de Joode, B., Mergler, D., and da Silva, A. S. (2016). Worker health and safety and climate change in the Americas: issues and research needs. RevistaPanamericana de SaludPública, 40, 192-197.

Kim, C. (2009). The Impact of Climate Change on the Agricultural Sector: Implications of the Agro-Industry for Low Carbon, 
Green Growth Strategy, and Road map for the East Asian Region. Retrieved August 25, 2020, from https://www.unescap.org/sites/default/file s/5.\%20The-Impact-of-Climate-Changeon-the-Agricultural-Sector.pdf

Kjellstrom, T., Briggs, D., Freyberg, C., Lemke, B., Otto, M., and Hyatt, O. (2016). Heat, human performance, and occupational health: a key issue for the assessment of global climate change impacts. Annual review of public health, 37, 97-112

Kjellstrom, T., Lemke, B., Otto, M., Hyatt, O., and Dear, K. (2014). Occupational heat stress. Tech. Rep. 2014:4. Health Environ. Int. Trust, Mapua, New Zealand. http://www. climatechip. org/sites/default/files/publications/TP201 4_4_Occupational_Heat_Stress_WHO. pdf.

Kjellstrom, T., Holmer, I., and Lemke, B. (2009). Workplace heat stress, health, and productivity-an increasing challenge for low and middle-income countries during climate change. Global health action, 2(1), 2047.

Kjellstrom, T., Kovats, R. S., Lloyd, S. J., Holt, T., and Tol, R. S. (2009). The direct impact of climate change on regional labor productivity. Archives of Environmental and Occupational Health, 64(4), 217-227.

Kjellstrom, T., Briggs, D., Freyberg, C., Lemke, B., Otto, M., and Hyatt, O. (2016). Heat, human performance, and occupational health: a key issue for the assessment of global climate change impacts. Annual review of public health, 37, 97-112.

Kjellstrom, T., Lemke, B., and Otto, M. (2017). Climate conditions, workplace heat, and occupational health in South-East Asia in the context of climate change. WHO South-East Asia Journal of Public Health, 6(2), 15-21.

Kovats, R. S., and Hajat, S. (2008). Heat stress and public health: a critical review. Annu. Rev. Public Health, 29, 41-55.

Krishnamurthy, M., Ramalingam, P., Perumal, K., Kamalakannan, L. P., Chinnadurai, J.,
Shanmugam, R.,. .. and Venugopal, V. (2017). Occupational heat stress impacts health and productivity in the steel industry in southern India. Safety and health at work, 8(1), 99-104.

Kumar, R., and Gautam, H. R. (2014). Climate change and its impact on agricultural productivity in India. Journal of Climatology and Weather Forecasting.

Laaidi, K., Zeghnoun, A., Dousset, B., Bretin, P., Vandentorren, S., Giraudet, E., and Beaudeau, P. (2012). The impact of heat islands on mortality in Paris during the August 2003 heatwave. Environmental health perspectives, 120(2), 254-259

Lam, M., Krenz, J., Palmández, P., Negrete, M., Perla, M., Murphy-Robinson, H., and Spector, J. T. (2013). Identification of barriers to the prevention and treatment of heat-related illness in Latino farmworkers using activity-oriented, participatory rural appraisal focus group methods. BMC Public Health, 13(1), 1004.

Levy, B. S., and Roelofs, C. (2019). Impacts of climate change on workers' health and Safety. In Oxford Research Encyclopedia of Global Public Health.116.Retrieved August 22. 2020, from https://oxfordre.com/publichealth/

Levy, B. S., and Patz, J. A. (eds): Climate change and public health, $1^{\text {st }}$ ed. New York, NY: Oxford University Press, 2015. P 448.ISBN: 9780190202453.

Lucas, R. A., Epstein, Y., and Kjellstrom, T. (2014). Excessive occupational heat exposure: a significant ergonomic challenge and health risk for current and future workers. Extreme physiology and medicine, 3(1), 14.

Lundgren, K., Kuklane, K., Gao, C., and Holmer, I. (2013). Effects of heat stress on working populations when facing climate change. Industrial Health, 51(1), 3-15.

Louis, M. E. S., and Hess, J. J. (2008). Climate change: impacts and implications for global health. American journal of preventive medicine, 35(5), 527-538.

Mahapatra, B., Walia, M., and Saggurti, N. 
(2018). Extreme weather events induced deaths in India 2001-2014: Trends and differentials by region, sex, and age group. Weather and climate extremes, 21 , 110-116.

Manisalidis, I., Stavropoulou, E., Stavropoulos, A., and Bezirtzoglou, E. (2020). Environmental and health impacts of air pollution: A review. Frontiers in public health, 8 .

McQueen, S. L. (2012). Evaluation of Heat Stress in Migrant Farmworkers.

Menne, B. (2005). Extreme Weather Events: What can We do to Prevent Health Impacts?. Extreme weather events and public health responses (pp. 265-271). Springer, Berlin, Heidelberg

Messeri, A., Morabito, M., Bonafede, M., Bugani, M., Levi, M., Baldasseroni, A.,. .. and Marinaccio, A. (2019). Heat stress perception among native and migrant workers in Italian industries - case studies from the construction and agricultural sectors. International journal of environmental research and public health, 16(7), 1090.

Moda, H.M., Filho, W.L., and Minhas, A. (2019). Impacts of Climate Change on Outdoor Workers and their Safety: Some Research Priorities. International Journal of Environmental Research and Public Health, 16(18), 1-21. DOI:10.3390/ijerph16183458.

Moher, D., Liberati, A., Tetzlaff, J., Altman, D. G., and PRISMA Group (2009). Preferred reporting items for systematic reviews and meta-analyses: the PRISMA statement. PLoS medicine, 6(7), e1000097.https://doi.org/10.1371/journal. pmed.1000097

Morioka, I., Miyai, N., and Miyashita, K. (2006). Hot environment and health problems of outdoor workers at a construction site. Industrial health, 44(3), 474-480.

Neidell, M. (2017). Air pollution and worker productivity. IZA World of Labor.

Nichols, A., Maynard, V., Goodman, B., and Richardson, J. (2009). Health, climate change, and sustainability: A systematic review and thematic analysis of the literature. Environmental health insights, 3, EHI-S3003.

Nilsson, M., and Kjellstrom, T. (2010). Climate change impacts on working people: how to develop prevention policies. Global Health Action, 3(1), 5774.

Noji, E. K. (2000). The Public Health Consequences of Disasters. Prehospital and Disaster Medicine. New York: Oxford Univ. Press. 15(04), 21-31. doi:10.1017/s1049023x00025255

Nunfam, V. F., Adusei-Asante, K., Van Etten, E. J., Oosthuizen, J., and Frimpong, K. (2018). Social impacts of occupational heat stress and adaptation strategies of workers: A narrative synthesis of the literature. Science of the total environment, 643, 1542-1552.

Nunfam, V. F., Van Etten, E. J., Oosthuizen, J., Adusei-Asante, K., and Frimpong, K. (2019). Climate change and occupational heat stress risks and adaptation strategies of mining workers: Perspectives of supervisors and other stakeholders in Ghana. Environmental Research, 169, 147-155.

Ogden, N. H. (2017). Climate change and vector-borne diseases of public health significance. FEMS microbiology letters, 364(19), fnx 186

Olsson, L., M. Opondo, P. Tschakert, A. Agrawal, S.H. Eriksen, S. Ma, L.N. Perch, and S.A. Zakieldeen, 2014: Livelihoods and poverty. In: Climate Change 2014: Impacts, Adaptation, and Vulnerability. Part A: Global and Sectoral Aspects. Contribution of Working Group II to the Fifth Assessment Report of the Intergovernmental Panel on Climate Change [Field, C.B., V.R. Barros, D.J. Dokken, K.J. Mach, M.D. Mastrandrea, T.E. Bilir, M. Chatterjee, K.L. Ebi, Y.O. Estrada, R.C. Genova, B. Girma, E.S. Kissel, A.N. Levy, S. MacCracken, P.R. Mastrandrea, and L.L.White (eds.)]. Cambridge University Press, Cambridge, United Kingdom, and New York, NY, 
USA, pp. 793-832.

Open Weather. (2018, March 22). UV-index as an indicator of U.V. radiation's effect on improving productivity within agriculture. Retrieved September 07, 2020, from https://medium.com/

Orru, H., Ebi, K. L., and Forsberg, B. (2017). The interplay of climate change and air pollution on health. Current environmental health reports, 4(4), 504513.

Ostfeld, R. S., and Brunner, J. L. (2015). Climate change and Ixodes tick-borne diseases of humans. Philosophical Transactions of the Royal Society B: Biological Sciences, 370(1665), 20140051.

Pal, G., and Chattopadhyay, P. (2020). Development and Testing of a Power Tiller Operated Single Row Potato Planter with Bucket Elevator type Metering Mechanism. Journal of Agricultural Engineering, 57(2), 85-96.

Padhy, S. K., Sarkar, S., Panigrahi, M., and Paul, S. (2015). Mental health effects of climate change. Indian journal of occupational and environmental medicine, 19(1), 3.

Park, J., Kim, Y., and Oh, I. (2017). Factors affecting heat-related diseases in outdoor workers exposed to extreme heat. Annals of occupational and environmental medicine, 29(1), 30.

Parsons, K. (2006). Heat stress standard ISO 7243 and its global application. Industrial Health, 44(3), 368-379.

Pogačar, T., Črepinšek, Z., Bogataj, L. K., and Lars, N. Y. B. O. (2017). Comprehension of climatic and occupational heat stress amongst agricultural advisers and workers in Slovenia. Acta Agriculturae Slovenica, 109(3), 545-554.

Powell, J. P., and Reinhard, S. (2016). Measuring the effects of extreme weather events on yields. Weather and Climate extremes, 12, 69-79.

Räsänen, A., Juhola, S., Nygren, A., Käkönen, M., Kallio, M., Monge, A. M., and Kanninen, M. (2016). Climate change, multiple stressors, and human vulnerability: a systematic review. Regional Environmental Change, 16(8), 2291-2302.

Raouf, A., 2012. Part VIII: accidents and safety management- accident prevention: theory of accident causes. In: Saari, J. (Ed.), ILO Encyclopaedia of Occupational Health and Safety. https://www.iloencyclopaedia.org/partviii

Rim, K. T., and Lim, C. H. (2014). Biologically hazardous agents at work and efforts to protect workers' health: a review of recent reports. Safety and health at work, 5(2), 43-52.

Roelofs, C., and Wegman, D. (2014). Workers: climate canaries. American journal of public health, 104(10), 17991801.https://doi.org/10.2105/AJPH.2014. 302145

Sadiq, S., Saboor, A., Jamshaid, F., Mohsin, A. Q., and Khalid, A. (2019). Assessment of Farmers' Vulnerability to Climate Change in Agro-Climatic Zones of Pakistan: An Index-Based Approach. Sarhad Journal of Agriculture, 35(3).

Sadiq, L. S., Hashim, Z., and Osman, M. (2019). The Impact of Heat on Health and Productivity among Maize Farmers in a Tropical Climate Area. Journal of environmental and public health, 2019.

Safi, M. (2017, July 31). Suicides of nearly 60,000 Indian farmers linked to climate change, study claims. Retrieved May 25, 2020, from https://www.theguardian.com

Sailor, D. J. (2011). A review of methods for estimating anthropogenic heat and moisture emissions in the urban environment. International journal of climatology, 31(2), 189-199.

Satterthwaite, D., McGranahan, G., and Tacoli, C. (2010). Urbanization and its implications for food and farming. Philosophical transactions of the Royal Society of London. Series B, Biological Sciences, 365(1554), 2809-2820. https://doi.org/10.1098/rstb.2010.0136.

Schulte, P. A., and Chun, H. (2009). Climate 
change and occupational safety and health: establishing a preliminary framework. Journal of occupational and environmental hygiene, 6(9), 542-554.

Schulte, P. A., Bhattacharya, A., Butler, C. R., Chun, H. K., Jacklitsch, B., Jacobs, T., Kiefer,M., Lincoln, J., Pendergrass, S., Shire, J., Watson, J., and Wagner, G. R. (2016). Advancing the framework for considering the effects of climate change on worker safety and health. Journal of occupational and environmental hygiene, 13(11), 847-865

Sett, M., and Sahu, S. (2014). Effects of occupational heat exposure on female brick workers in West Bengal, India. Global health action, 7(1), 21923

Sherwood, S. C., and Huber, M. (2010). An adaptability limit to climate change due to heat stress. Proceedings of the National Academy of Sciences, 107(21), 95529555.

Sheng, R., Li, C., Wang, Q., Yang, L., Bao, J., Wang, K.,. .. and Bi, P. (2018). Does hot weather affect work-related injury? A case-crossover study in Guangzhou, China. International journal of hygiene and environmental health, 221(3), 423428.

Shortridge, J., and Paoletti, J. (2018). Managing Climate Risks and Extreme Weather in Agriculture. Retrieved August 28, 2020, from https://vtechworks.lib.vt.edu/bitstream/

Singh, S., Ahlawat, S., and Sanwal, S. (2018). Effect of Heat Stress on Farm Workers-A Review. Int. J. Curr. Microbiol. App. Sci, 7(10), 2397-2401.

Sorensen, C., Murray, V., Lemery, J., and Balbus, J. (2018). Climate change and women's health: Impacts, and policy directions. PLoS medicine, 15(7), e1002603.

Srinivasan, K., Maruthy, K. N., Venugopal, V., and Ramaswamy, P. (2016). Research in occupational heat stress in India: Challenges and opportunities. Indian journal of occupational and environmental medicine, 20(2), 73.
StaalWästerlund, D.( 2018). Managing heat in agricultural work: increasing worker safety and productivity by controlling heat exposure. Forestry Working Paper No. $\quad 1 . \quad$ Rome, FAO. http://www.fao.org/3/i9179en/I9179EN. pdf

Stevens, M. (2016, November 27). Human Body Heat as a Source for Thermoelectric Energy Generation. Retrieved September 02, 2020, from http://large.stanford.edu/courses

Sutter, S. (1994). A GUIDE TO AGRICULTURAL HEAT STRESS. Retrieved August 26, 2020, from http://lib.ncfh.org/pdfs/7392.pdf

Swaminathan, M. S., and Rengalakshmi, R. (2016). Impact of extreme weather events in Indian agriculture: Enhancing the coping capacity of farm families. Mausam, 67(1), 1-4.

Thomas, F., Sabel, C. E., Morton, K., Hiscock, R., and Depledge, M. H. (2014). Extended impacts of climate change on health and wellbeing. Environmental Science and Policy, 44, 271-278.

Tustin, A. W., Lamson, G. E., Jacklitsch, B. L., Thomas, R. J., Arbury, S. B., Cannon, D. L., and Hodgson, M. J. (2018). Evaluation of occupational exposure limits for heat stress in outdoor workers-United States, 2011-2016. Morbidity and Mortality Weekly Report, 67(26), 733.

UNDP.Climate Change and Labour: Impacts of Heat in the Workplace Climate Change, Workplace Environmental Conditions, Occupational Health Risks, and Productivity-An Emerging Global Challenge to Decent Work, Sustainable Development, and Social Equity. 2016. (Retrieved September 07, 2020, from https://www.undp.org/content/undp/en/ho me.html

Varghese, B. M., Barnett, A. G., Hansen, A. L., Bi, P., Hanson-Easey, S., Heyworth, J. S., and Pisaniello, D. L. (2019). The effects of ambient temperatures on the risk of work-related injuries and illnesses: Evidence from Adelaide, Australia 2003- 
2013. Environmental Research, 170, 101109.

World Health Organization. (2018). Occupational Safety and health in public health emergencies: a manual for protecting health workers and responders.

Walljasper, C. (2019, August 02). Extreme Heat May Hurt Farms, Agriculture Industry: Report. Retrieved May 23, 2020, from https://www.insurancejournal.com/news/ midwest $/ 2019 / 08 / 02 / 534597 . h t m$

World Health Organization. (2003). Ultraviolet Radiation as a Hazard in the Workplace. Online: www.who. int/pehuv/Info_sheet/UV_Occupational_Risk. pdf.

Wilson, L., Detoyato, A., Han, L. M., Joseph, L., and Chye, E. Y. (2012). ActivityBased Risk Assessment for Asphalt Paving. Retrieved September 13, 2020, from https://studylib.net/doc/9731370/activitybased-risk-assessment-for-asphalt-paving

Xiang, J., Hansen, A., Pisaniello, D., and Bi, P. (2016). Workers' perceptions of climate change-related extreme heat exposure in South Australia: A cross-sectional survey. BMC Public Health, 16(1), 549.

Xiang, J., Bi, P., Pisaniello, D., and Hansen, A. (2014). The impact of heatwaves on workers' health and Safety in Adelaide,
South Australia. Environmental Research, 133, 90-95.

Xiang, J., Hansen, A., Pisaniello, D., and Bi, P. (2016). Workers' perceptions of climate change-related extreme heat exposure in South Australia: A cross-sectional survey. BMC Public Health16(1), 549.

Xiang, J., Bi, P., Pisaniello, D., and Hansen, A. (2014). Health impacts of workplace heat exposure: an epidemiological review. Industrial Health, 52(2), 91-101. https://doi.org/10.2486/indhealth.20120145

Ylipaa, J., Gabrielsson, S., and Jerneck, A. (2019). Climate change adaptation and gender inequality: insights from rural Vietnam. Sustainability, 11(10), 2805.

Żukiewicz-Sobczak, W. A., ChmielewskaBadora, J., Wróblewska, P., and Zwoliński, J. (2013). Farmers occupational diseases of allergenic and zoonotic origin. Advances in Dermatology and Allergology/PostępyDermatologiiiAlergol ogii, 30(5), 311.

Zamanian, Z., Sedaghat, Z., Hemehrezaee, M., and Khajehnasiri, F. (2017). Evaluation of environmental heat stress on physiological parameters. Journal of Environmental Health Science and Engineering, 15(1), 24.

\section{How to cite this article:}

Govinda Pal, Thaneswer Patel and Trishita Banik. 2021. Effect of Climate Change Associated Hazards on Agricultural Workers and Approaches for Assessing Heat Stress and Its Mitigation Strategies - Review of Some Research Significances. Int.J.Curr.Microbiol.App.Sci. 10(02): 2947-2975. doi: https://doi.org/10.20546/ijcmas.2021.1002.325 